p-ISSN: 0125-961X

Scientific Article

\title{
OBSERVATION SERIES OF FLOWERING AND FRUITING PHENOLOGY OF Mischocarpus pentapetalus (Roxb.) Radlk. (SAPINDACEAE) IN CIBODAS BOTANIC GARDENS, 2014-2018
}

\author{
Serangkaian pengamatan fenologi pembungaan dan pembuahan Mischocarpus pentapetalus (Roxb.) Radlk. \\ (Sapindaceae) di Kebun Raya Cibodas, 2014-2018
}

\author{
Imawan Wahyu Hidayat ${ }^{1,2^{*}}$, Yudi Suhendri \\ ${ }^{1}$ Research Center for Plant Conservation and Botanic Gardens, Indonesian Institute of Sciences (LIPI), \\ Jalan Ir. H. Juanda 13, Bogor, West Java, Indonesia 16122 \\ ${ }^{2}$ Cibodas Botanic Gardens, Indonesian Institute of Sciences (LIPI), Sindanglaya, Pacet-Cipanas, Cianjur, Indonesia 43253
}

\section{Informasi Artikel}

Diterima/Received : 15 Juni 2020

Disetujui/Accepted : 30 November 2020

Diterbitkan/Published : 1 Desember 2020

*Koresponden E-mail :

imawan.wahyu.hidayat@lipi.go.id

\section{DOI: https://doi.org/10.14203/bkr.v23i3.658}

Cara mengutip

Hidayat IW, Suhendri Y. 2020. Observation series of flowering and fruiting phenology of Mischocarpus pentapetalus (Roxb.) Radlk (Sapindaceae) in Cibodas Botanic Gardens, 2014-2018. Buletin Kebun Raya 23(3): 196209. DOI:

https://doi.org/10.14203/bkr.v23i3.658

\section{Kontributor}

Kontributor Utama/Main author:

Imawan Wahyu Hidayat

Kontributor Anggota/Author member: Yudi Suhendri

\begin{abstract}
Abstrak
Mischocarpus pentapetalus (Roxb.) Radlk. merupakan tumbuhan potensial untuk dikembangkan sebagai pohon buah dan kayu. Pengamatan komprehensif terhadap tahap reproduksi spesies ini masih terbatas. Untuk mendapatkan pengamatan berkelanjutan dan berurutan, studi fenologi ini dilakukan di Kebun Raya Cibodas (KRC). Studi ini bertujuan mengamati fase berbunga dan berbuah $M$. pentapetalus dan menganalisis efek iklim mikro yang terkait dengan siklus hidupnya. Pengamatan dilakukan pada tiga spesimen pohon $M$. pentapetalus yang ditanam pada Januari 1979 (Spesimen I), Januari 1985 (Spesimen II), dan Januari 1987 (Spesimen III) di KRC. Studi ini menggunakan analisis kuantitatif deskriptif berdasarkan pengamatan inventarisasi eksplorasi data fase berbunga dan berbuah pada Spesimen I dan kondisi iklim mikro, yang keduanya dinilai dari 2014 hingga 2018. Spesimen II dan III hanya diamati fenologinya pada 2019. Hasilnya menunjukkan bahwa kondisi iklim mikro KRC selama lima tahun relatif kurang beragam, kecuali untuk presipitasi ( $\sigma \approx 1.367$ ). Hal ini diduga mempengaruhi tahap reproduksi yang dominan terjadi pada awal dan akhir tahun. Pada periode ini terjadi peningkatan curah hujan yang muncul bunga dan perkembangan selanjutnya ke fase berbuah. Panen biji dan stok ulang disarankan dilakukan pada periode ini untuk mencapai hasil maksimal.
\end{abstract}

\begin{abstract}
Mischocarpus pentapetalus (Roxb.) Radlk. is a potential plant to be developed as a fruit tree and timber. A comprehensive observation of the reproductive stage of this species is still limited. In order to achieve a continuous and sequenced observation, a phenological study was conducted in Cibodas Botanic Gardens (CBG). This study aimed to observe the flowering and fruiting phase phenology of M. pentapetalus and analyze the microclimate's effect related to the cycle. The observation conducted to three specimens of $M$. pentapetalus which were planted in January 1979 (Specimen I), January 1985 (Specimen II) and January 1987 (Specimen III), at CBG. The study used descriptive quantitative analysis based on the exploratoryinventory observation of flowering and fruiting phase data of Specimen I, and the microclimate conditions, both are assessed from 2014 to 2018. Specimen II and III were only observed for their phenology in 2019. The results showed that the microclimates condition of CBG for five years was relatively less diverse, except for precipitation $(\sigma \approx 1.367)$. This results suspected influenced the reproductive stages that dominantly occurred in the early and at the end of the year. In these periods occurred an increase in rainfall that emerges the flowers and next- development into the fruiting phase. Seeds harvesting and (re)stock suggested can be conducted on these periods in order to achieve maximum results.
\end{abstract}

Kata Kunci: fenologi, Kebun Raya Cibodas, Mischocarpus pentapetalus, pembuahan, pembungaan

Keywords: Cibodas Botanic Gardens,

flowering, fruiting, Mischocarpus

pentapetalus, phenology

\section{INTRODUCTION}

For a long time, most forest products in Indonesia known and considered of high economic value are the results of the wood. However, there are a group of plant species as fruit producers that are recently widely known.
This is because forest fruits are considered as 'minor product' with economically less important (Uji 2007). The diversity of species and germplasm of Indonesian native fruits are broad, especially important value as a basic asset for fruit plant breeding. There are 226 species of native Indonesian fruit plants are edible, most of which 
grow wild in the forest (184 species), only a small proportion have been cultivated (62 species) and 18 of them are endemic (Uji 2007; Dodo 2015).

One of the important families as fruit plant is Sapindaceae and it is incredibly diverse in Indonesia (Uji 2007). Indeed, Sapindaceae is well known for their importance as the food source (Uji 2007; Buerki et al. 2013; Milow et al. 2014; Dodo 2015) and chemical constituents (Manfron et al. 2010; Padulosi et al. 2011; Raza et al. 2013). These 26 species of Sapindaceae are edible (Uji 2007) and potentially to be developed as fruit diversification in Indonesia (Uji 2007). One of them is Mischocarpus pentapetalus (Roxb.) Radlk. or ki hoe (Sundanese) (Rozak et al. 2016; Hendrawan et al. 2019); bebak (Javanese) (Uji 2007); kedupai (Borneo) (DiazNovellon et al. 2004); or rambutan pucat (Bahasa Indonesia) (Jansen et al. 1991; Uji 2007; Normasiwi \& Surya 2016).

This species is an evergreen tree up to $25 \mathrm{~m}$ tall and the habitat in both primary and secondary forests, growing in mixed dipterocarp, coastal (mangrove edges, beach edges), and sub-montane forests, both on slopes and ridges as well as by rivers and streams; at elevations up to 2,000 $\mathrm{m}$ asl. The distribution from India through Indo-China to China and Malesia (New Guinea excepted) (Jansen et al. 1991). The fruit of M. pentapetalus is edible with reddish fruit, subglobose to ellipsoid capsule, usually 10-20 (30) $\mathrm{mm}$ in diameter, splitting into 2-3 sections, each with a seed enveloped by a thinly fleshy, orange arillode (Jansen et al. 1991; Gardner et al. 2000). The stem wood can be used as a tonic after childbirth (Gardner et al. 2000).

M. pentapetalus is a large tree, and the wood is straight, heavy, fine and durable (Hong 2017), so it perhaps can be used as a construction material. Even this tree is 'not assessed' (NA) by IUCN Redlist as threatened species (IUCN 2020), but the existence of this species in the wild is important to support the habitat of the threatened animals, such as langurs or javan lutung (Hendrawan et al. 2019) and orangutans (Lee et al. 2019). Moreover, $M$. pentapetalus to be recommended as a preferred species for forest rehabilitation in Kutai National Park to support orangutans (Lee et al. 2019).

Therefore, in order to support the conservation efforts and ensure the sustainability of this tree species as an asset for breeding in the future (Uji 2007; Milow et al. 2014; Normasiwi \& Surya 2016), it needs to gather information of flowering and fruiting phase phenology of M. pentapetalus. These are used in the future to plan seed collection and to produce a mass seedling. There is only limited and general information about this species' phenological cycle of this species (Jansen et al. 1991). There are several reasons concerning the importance to construct the phenological pattern, such as to support the conservation efforts (Morellato et al. 2016), to explore function of the ecosystem data (Pau et al. 2011), to obtain seasonality data for crop and to do farm work in the right season (Abbas et al. 2017; Tariq et al. 2018), to determine the appropriate time for plant seed collection (Ritchie et al. 2017; Luna-Nieves et al. 2017), to observe the relation between abiotic factors with phenology (Scheffers et al. 2016; Dunham et al. 2018), etc.

In addition to observing the phenology phase made in the wild, a comprehensive observation can also be made in a manageable environment. In botanic gardens, the phenology observation of a species is conducting sequentially, usually weekly. This study aimed to assess the flowering and fruiting phenology of $M$. pentapetalus for five years (from 2014 to 2018) at Cibodas Botanic Gardens, and analyze the effect of the garden's microclimate related to the phenology cycles. This study is expected to support the conservation efforts of $M$. pentapetalus, especially for the seeds harvesting period and to (re)stock for further propagation needs.

\section{MATERIALS AND METHODS}

\section{Study site}

The study was conducted at Cibodas Botanic Gardens (CBG), Cianjur, West Java. The geographical location of CBG is at $107^{\circ} 0^{\prime} 10.476^{\prime \prime}$ to $107^{\circ} 0^{\prime} 59.275^{\prime \prime} \mathrm{E}$ and $6^{\circ} 44^{\prime} 6.787^{\prime \prime}$ to $6^{\circ} 44^{\prime} 51.112^{\prime \prime} \mathrm{S}$. CBG is located at the eastern mountainside of Mount Gede-Pangrango, with an altitude of approximately 1,300-1,425 $\mathrm{m}$ asl., with an area of \pm 84.99 ha. The average temperature is $20{ }^{\circ} \mathrm{C}$, the humidity of $80.82 \%$ and the average rainfall of $2,950 \mathrm{~mm}$ per year (Registration Unit-CBG 2018a). CBG is ex-situ plant conservation with various types of plants that mostly originated from Indonesia, with more than $60 \%$ of the collections, especially from the wet tropical mountainous zone and other foreign countries.

\section{Study samples}

The subject of the study was three specimens of M. pentapetalus planted in the garden in January 1979 (Specimen I), January 1985 (Specimen II), and January 1987 (Specimen III) (Registration Unit-CBG 2018b). Specimen I was observed from 2014 to 2018, and Specimen II and III were only in 2019. The morphology traits of the specimens are described in Table 1 . The preview of the specimens can be observed in Figure 1.

Table 1. Morphological traits of the observed specimens of $M$. pentapetalus. 


\begin{tabular}{lcccc}
\hline $\begin{array}{c}\text { Specimens of } \\
\text { M. pentapetalus }\end{array}$ & Planted in & Height $(\mathbf{m})$ & $\begin{array}{c}\text { Diameter of } \\
\text { breast height } \\
(\mathbf{c m})\end{array}$ & $\begin{array}{c}\text { Diameter of } \\
\text { canopy } \\
(\mathbf{m})\end{array}$ \\
\hline Specimen I & January 1979 & $5.94 \pm 0.05$ & $28.95 \pm 0.05$ & $10.37 \pm 0.05$ \\
Specimen II & January 1985 & $5.5 \pm 0.05$ & $29.02 \pm 0.05$ & $9.12 \pm 0.05$ \\
Specimen III & January 1987 & $9.7 \pm 0.05$ & $26.41 \pm 0.05$ & $8.3 \pm 0.05$ \\
\hline
\end{tabular}
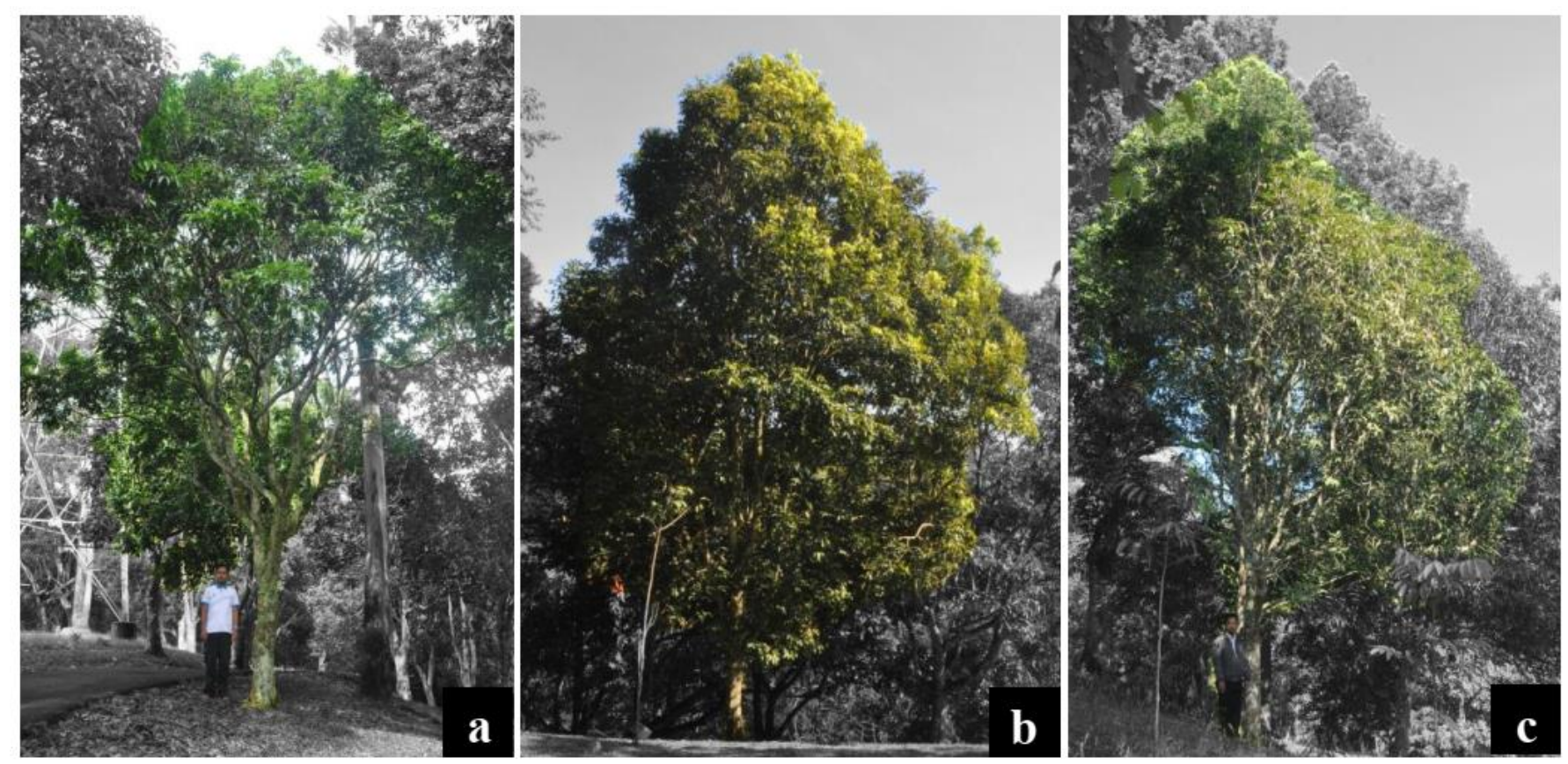

Figure 1. M. pentapetalus tree of CBG as the subject of the study: (a) Specimen I; (b) Specimen II; (c) Specimen III. (Photograph by: Yudi Suhendri).

\section{Data collection}

The collected database consisted of two main data, microclimates data (i.e. temperature, humidity, precipitation, and wind velocity) and the observation records of flowering and fruiting phenology of $M$. pentapetalus. The microclimates data recorded from 2014 to 2018. All microclimates data collected from the weather station established at CBG. The observation equipment located in front of the management office of CBG. The collected data were accurate to describe weather conditions surrounding equipment minimum in a radius of the $1 \mathrm{~km}^{2}$.

The weather equipment was automatic constantly sent current data to the server regarding the microclimates' observed of CBG. The data from the server collected hourly then accumulated in daily data.

The following data was the observation records of the flowering and fruiting phenology of $M$. pentapetalus. This reproductive study was conducted by documenting the observations of the frequencies of flowering and fruiting events (Hatta et al. 2005). The reproductive growth stages consist: (i) flower buds, (ii) flowering, (iii) young fruits, and (iv) ripe fruits. These events documented based upon the following five different categories: Rank 5 is defined by more than $80 \%$ of flowering or fruiting (abundant); Rank 4, flowering or fruiting on 60 to $80 \%$ (moderately abundant); Rank 3, flowering or fruiting on 30 to $60 \%$ (moderate); Rank 2, flowering or fruiting less than $30 \%$ (rare), and Rank 1 without flowering or fruiting, $0 \%$ (nothing) (Hatta et al. 2005).

\section{Data analysis}

The microclimates' daily data were then processed, presented monthly depends on the unit, such as temperature, humidity, and wind velocity, and presented in the average value and precipitation data describing the sum of rain volume. In data analysis, the microclimates' data will be presented quantitatively.

Along with data analysis, in order to resolve differences among the microclimates' data, both in value and unit, the number will be transferred in natural logarithm, In $\left(x_{i}\right)$. The amount of variation of these data series determined by a standard deviation $(\sigma)$. A low $\sigma$ indicates that the data points tend to be close to the mean or less variety, while a high $\sigma$ indicates that the data are spread out over a broader range of values or much variety (Widodo \& Andawaningtyas 2017). 
The reproductive stages of all specimens of $M$. pentapetalus were presented through a monthly timeseries each year, based on the rank of each phase of reproductive growth. All collected data were shown in a graphic form.

\section{RESULTS AND DISCUSSION}

Microclimates data series surrounding CBG and reproductive stages of $M$. pentapetalus at CBG from 2014 to 2018 were described below. There was a difference value trend both in month and year.

\section{Cibodas microclimates variability from 2014 to 2018}
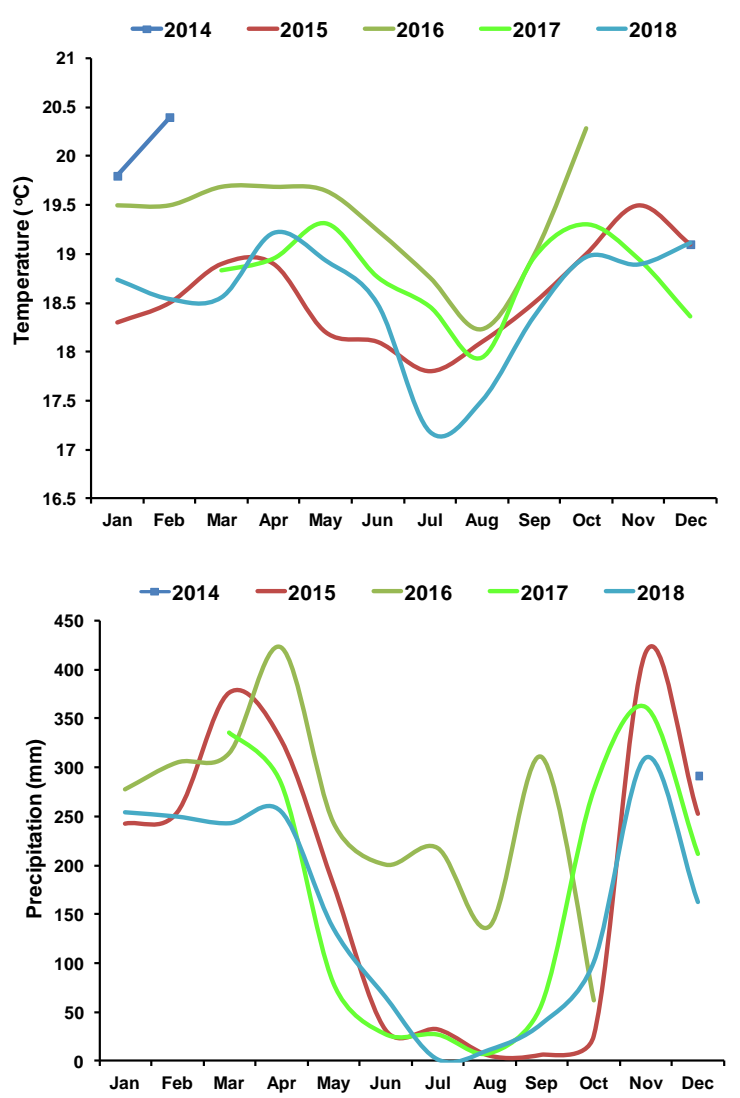

Microclimates data series of CBG from 2014 to 2018 were presented in detail in Figure 2. However, for several times, it could not be conducted recording the data caused by the errors either in the weather equipment or the server. All data were occurred error in March to November of 2014, November and December 2016, and February 2017. Another error were also found in precipitation data from January to February 2014, and so January to February 2017. Therefore, only three months' data were recorded in 2014, except precipitation which only one-month data in December, and still used in the calculation.

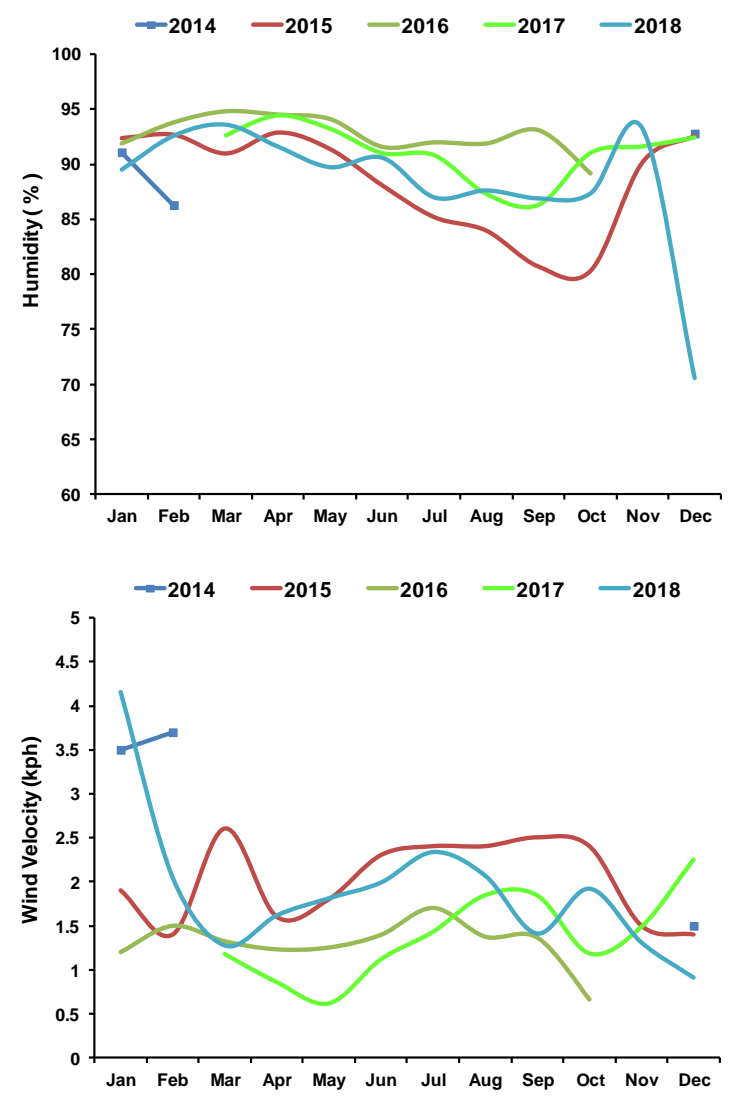

Figure 2. Dynamic microclimates conditions (i.e. temperature, humidity, precipitation, and wind velocity) of CBG from 2014 to 2018.

Based on microclimates data series from 2014 to 2018, the unit which has the widest amplitude was precipitation $(\sigma \approx 1.37$ ) and also had interannual variety (except 2014), but the other units only have minor data variety $(\sigma<1)$ (Table 2$)$. The temperature and humidity were less diverse neither inter month in a year and interannual. On the other hand, wind velocity only has slight diversity. These conditions in accordance with the low-mid montane with wet tropic zone characteristics described by Underwood et al. (2014), where CBG included in this zone.
Based on the data, heavy rainfall ( $\geq 100 \mathrm{~mm}$ per month) occurred in the early to end of the year (wet season), along with this, solar radiation decreased. This can be understood when heavy rainfall occurred, cloud covers very thick, and prevents solar radiation penetrations. Furthermore, rainfall occurred closely related to air pressure differences, bigger differences will give a bigger chance for the occurrence of rain. 
Table 2. Standard deviation $(\sigma)$ value of the normalized microclimates unit $\left(\ln \left(x_{i}\right)\right)$.

\begin{tabular}{lrrrrrc}
\hline $\begin{array}{c}\text { Microclimates } \\
\text { unit } \\
\left(\boldsymbol{x}_{\boldsymbol{i}}\right)\end{array}$ & \multicolumn{7}{c}{$\begin{array}{c}\sigma \text { value } \\
{\left[\text { of } \ln \left(\boldsymbol{x}_{\boldsymbol{i}}\right)\right]}\end{array}$} \\
\cline { 2 - 7 } & $\mathbf{2 0 1 4}$ & $\mathbf{2 0 1 5}$ & $\mathbf{2 0 1 6}$ & $\mathbf{2 0 1 7}$ & $\mathbf{2 0 1 8}$ & $\begin{array}{c}\text { Total } \\
\text { (2014 to 2018) }\end{array}$ \\
\hline Temperature & 0.032971 & 0.027103 & 0.030021 & 0.066105 & 0.034193 & 0.04529 \\
Humidity & 0.03773 & 0.05455 & 0.01851 & 0.04711 & 0.07506 & 0.05462 \\
Precipitation & n.d. & 1.60277 & 0.54435 & 1.32077 & 1.58183 & 1.36607 \\
Wind velocity & 0.505993 & 0.240261 & 0.25293 & 0.809565 & 0.377807 & 0.54107 \\
\hline
\end{tabular}

Note: n.d.: not detected, caused by only contain single data record in December. (Source: data processing)

The rainfall gives a significant variant of the microclimates' condition of CBG and the surrounding. CBG and the surrounding included in a zone characterized by the number of wet months more than dry months, between seven to eight months per year, and accumulatively above $1,000 \mathrm{~mm}$ annual rainfall (MuellerDombois \& Fosberg 2013; Corlett 2014). CBG is the type of $C$ to $B$, or less wet to wet, based on Schmidt-Ferguson classification, and it can be included in tropical rainy climates or wet tropics 'Am' based on Koppen (Corlett 2014).

\section{Periods of flowering and fruiting of $M$. pentapetalus in Cibodas}

The characters of leaves and fruit of $M$. pentapetalus in CBG showed in Figure 3. Then, the data analysis showed that there were various differences from 2014 to 2018 for Specimen I (Figure 4), and Specimen II and III in 2019 (Figure 5), either the flowering or fruiting periods. All rank assessments of flowering and fruiting for all specimens of $M$. pentapetalus are presented in Appendix I, II, and III. In 2014, the stages of Specimen I was only cover the arise of flower buds to flowering periods and did not achieve to fruiting stages yet. It is suspected that the flowering phase is still in the early stages of development. In addition, the high volume of rainfall in December 2014 (291.8 mm) was also considered to be the cause of buds that were still undeveloped (Dunham et al. 2018). These also only occurred at the end of the year in a shorter time. The period begins in the first week to the end of December, approximately only a month.

However, this flowering development continues to proceed through early 2015, until the second week of January. Some flowers were also succeeded to grow into young fruits. These young fruits continued into ripe fruits that started in the second of March to the end of April. Furthermore, it is also recorded that occurred flower buds and flowers at the end of the year that started in the third week of October until the end of the year. This almost similar to 2014, at the end of this year the fruiting stages have also not occurred yet. This process also continues until early 2016 that flowering still found in the first week of January along with the rise of young fruits. The ripe fruits began to be seen in the fourth week of February until the first week of April. All these previous processes together with the increase of the rainfall conditions.
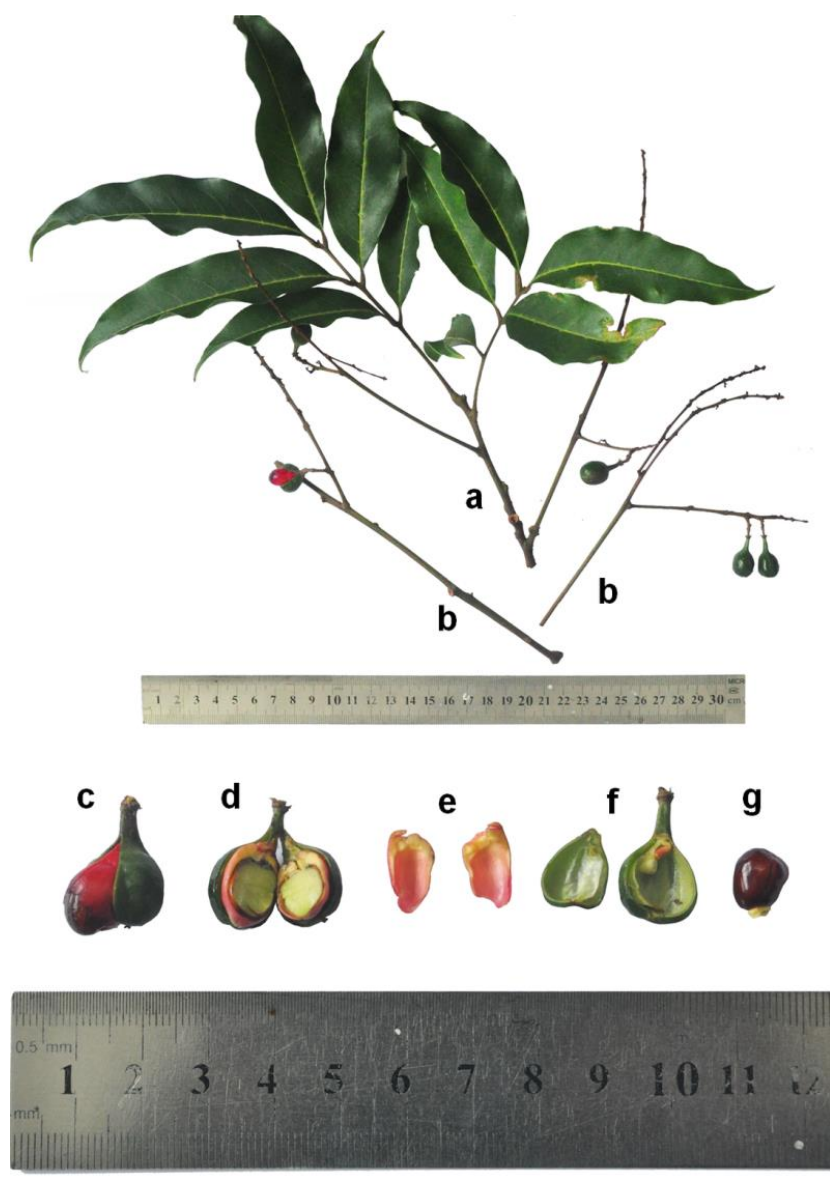

Figure 3. Mischocarpus pentapetalus (Roxb.) Radlk. a. Leaves with petiole and young fruit; b. multibranced fruits; c. young fruit. d. fruit in longitudinal section, showing fleshy pericarp and stony seed coat; e. arillode; f. pericarp; g. seed. (Photograph by: Yudi Suhendri). 

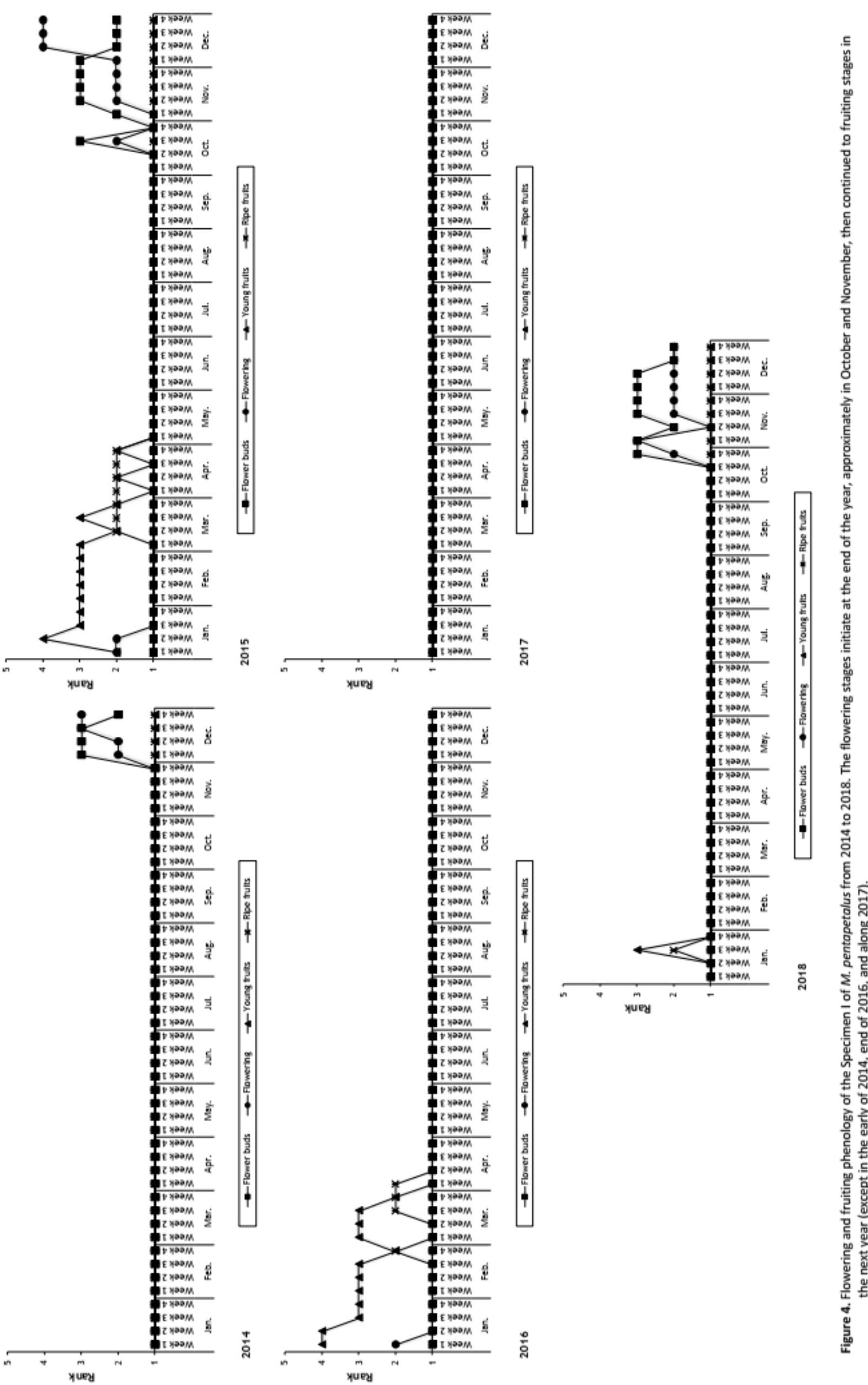


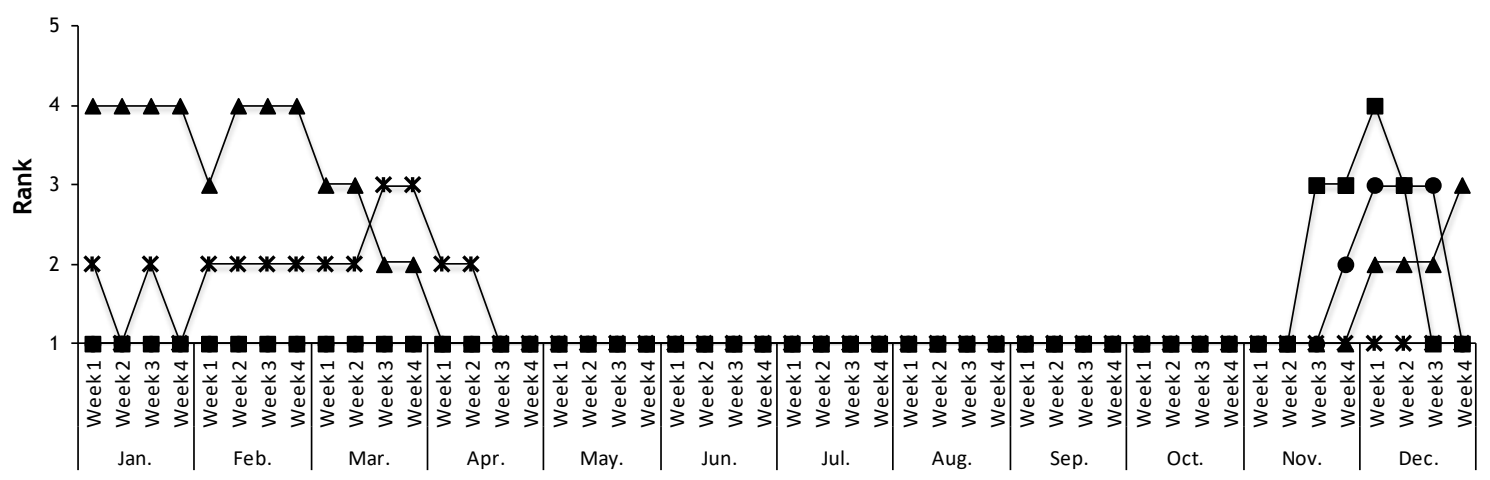

2019

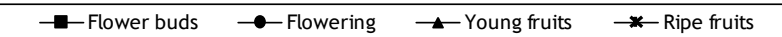

a

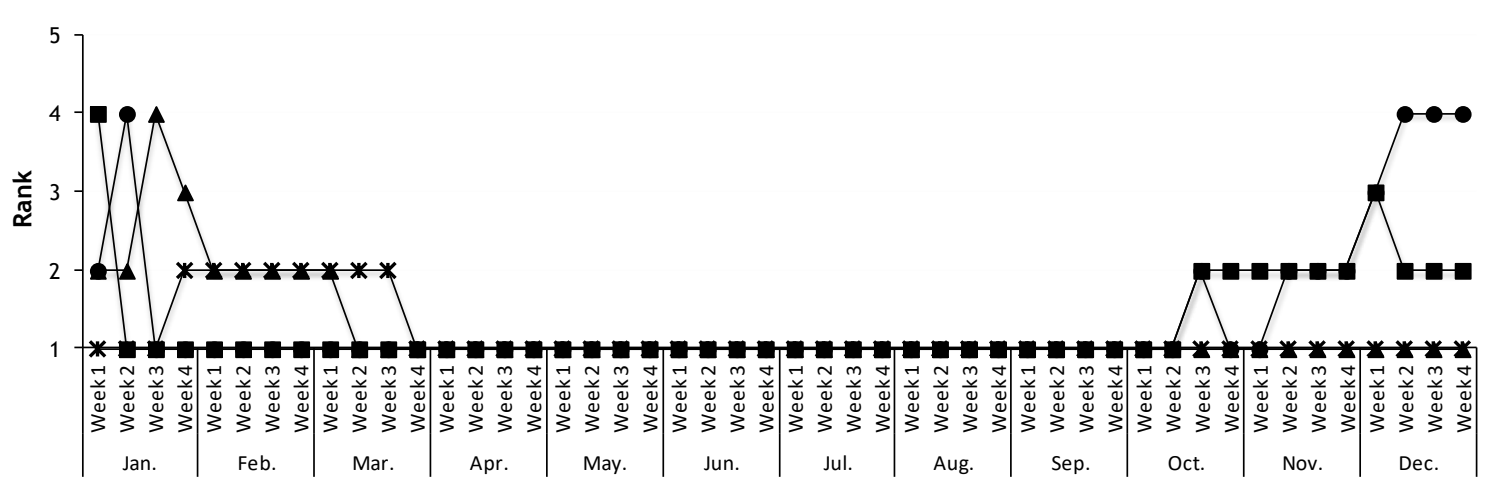

2019

Figure 5. Flowering and fruiting phenology M. pentapetalus in 2019: (a) Specimen II; (b) Specimen III.

The volume of rainfall which starts to increase along with the end of dry season is considered to be a trigger for the flowering phase (Hamann 2004; Prabhakar 2011). It started in mid-October and continues to the end of the year, and still going into the next following year. Later, the fruiting phases initiate in the early of January and achieve a peak in April. The high volume of rainfall (> $100 \mathrm{~mm}$ per month) or wet months occurred at the early and the end of the year of 2015 and 2016, especially started from January to April and mid-October to the end of December.

Furthermore, at the end of 2016, the Specimen I did not show the occurring of the generative stages. This was a unique condition considering the previous pattern that the flowering phase suppose to be started in this period. Since the end of 2016 and throughout 2017, there were no records showing the development of flowering and fruiting phenology of $M$. pentapetalus. This phenomenon may not be clearly explained and needs to be further research.

However, the volume of rainfall throughout 2016 was suspected to continue to April 2017 (almost) at a high level. The level of precipitation in 2016 less diverse than other years or relative constantly higher than $60 \mathrm{~mm}$ per month (Table 1). These conditions caused the absence of water supply differences to the plant which triggering the reproductive stages (Hamann 2004; Prabhakar 2011), similar to the previous periods (2014 to 2015, and 2015 to early 2016). These conditions considered lead to the absence of the flowering and fruiting of $M$. pentapetalus at the end of 2016 to early 2017.

In addition, the absence of the reproductive stage of M. pentapetalus has also occurred at the end of 2017. Even it found a leap of the precipitation level that started at the end of September, it did not trigger the reproductive stage. Although it is not clearly visible on the graph, it is noted that from October 2017 to early 2018, CBG and its surroundings experienced 'extreme weather events'. It has occurred a high level of rainfall mixed with the high speed of the wind. Both, when they occur in high intensity and during flowering, greatly reduce pollination. The extreme precipitation may lead to reductions in plant growth and increases in mortality up to 60\% (Zeppel et al. 2014). The high speed of wind retards growth through increased cold, halts growth, or through reduction of photosynthesis because less leaf surface is exposed to the sun (Gardiner et al. 2016).

The wind velocity reached $83.7 \mathrm{kph}$ and rainfall was always above $100 \mathrm{~mm}$ per month from October 2017 to January 2018. This high speed of the wind has been massively damaging the garden collections. There were more than fifty plant specimens have died, either 
collapsed, struck down by larger plants, or washed away by the flood. Some of those plants were tall trees and some were shrubs, and mostly has aged more than five years.

These conditions also presumed to support the explanation of why at the end of 2017 and in early 2018 the reproductive stage of $M$. pentapetalus not recorded, except only in the third week of January 2018. The stage assumed that the pollination was undeveloped due to these extreme conditions. The young and ripe fruits only recorded for about two weeks. Then, at the end of 2018, $M$. pentapetalus began to re-enter the reproductive stage started with the development of flower buds and also flowers at the late of October until the end of the year, but yet to show the rise of fruits.

In 2019, the next observation conducted to a different specimen of $M$. pentapetalus, which are Specimens II and III. In early 2019, Specimen II only experienced the fruiting stage from January until midApril. It is possible the flowering stage occurred in the last months of the previous year. Moreover, Specimen III experienced both the flowering and fruiting stages in early 2019. The flowering stage occurred in early January and continued with the fruiting stage toward the end of March.

Specimen II and III were also showed the absence of reproductive stages in the middle of the year. Then, Specimen II initiated the flowering stages in midNovember but Specimen III at the end of October. Both patterns also showed nearly the same pattern as Specimen I, especially in 2015. Due to the weather equipment's error in 2019 which results in the inability to record the data, then the reproductive observation in 2019 did not include the microclimate influence on the discussions. The results of this study suggested that seed harvesting of $M$. pentapetalus can be conducted during peak fruiting seasons that occurred at the early of the year.

Several factors may influence the timing of flowering and fruiting including rainfall, moisture, temperature and photoperiod (Gunter et al. 2008). It seems that the pattern of fruiting and flowering in this study may coincide with the fluctuation of rainfall. At the end of the dry season, in mid-October, the volume of rainfall starts to increase. Some species also showed similarities to with the above pattern such as Mangifera indica (Makhmale et al. 2016), Barringtonia acutangula (Nath et al. 2016), and Bauhinia variegata (Dutta \& Devi 2015). The flowering of $M$. indica commences in India around the first week of December in the southern part of Kerala and Tamil Nadu along with the increase of rainfall. The flowering and fruiting of $B$. aculata also correlated positively with rainfall, and the rank of correlation coefficients $(r)=0.89$ and 0.835 , and both are significant correlations. Furthermore, B. variegata initiates to enter the flowering time from October to November and develop into the fruit from December to January of the next of the year during the wet season.

The increase of rainfall after the end of the dry season, in which the precipitation tends to low, triggering the rise of flower buds of $M$. pentapetalus as the beginning of the reproductive stages. The precise timing of flowering and fruiting could be site-specific (Gunter et al. 2008). Site-specific defines as specific characters that only belong to one location and distinguish it from other locations, in relation to the phenological phase (e.g. microclimate, micro-topography, soil biochemical, water cycle, etc.).

The complex interactions among species physiologies, local conditions, and intra-annual variation in the timing of rainfall, lead to considerable variation in the timing, duration, and magnitude of phenology cycle among the tree species (Williams et al. 2008). Correlation between phenology and rainfall patterns may also be complicated by environmental heterogeneity and sitespecific variation that may influence the association between rainfall and water availability to an individual.

\section{CONCLUSIONS}

The study showed that microclimates condition in CBG relatively less diverse, except for precipitation. Precipitation is also suspected as influencing the reproductive stages of $M$. pentapetalus. The leap of the rainfall volume that occurred early and at the end of the year becomes an important factor in the emergence of the flowers and its development into fruits. Therefore, seed harvesting can be conducted during peak fruiting seasons that occurred in the early of the year (January to April). However, the study also noted that extreme weather events could break the pattern. A high level of precipitation along-year mixed with high speed of wind ruins the flowering which usually occurs at the end of the year. Furthermore, in order to understand the internal and external factors that influence the reproductive stages of species must integrate detailed physiological studies to complement the growing body of correlative and descriptive studies of phenology.

\section{ACKNOWLEDGEMENTS}

Our grateful towards all staff of CBGs' Registration Unit, especially to Agus Darmawan for compiling the microclimates data series, and also Dadan Hidayat and 
Uus Rustandi for cooperation in data compilation of flowering and fruiting periods.

\section{REFERENCES}

Abbas G, Ahmad S, Ahmad A, Nasim W, Fatima Z, Hussain S, ur Rehman MH, Khan MA, Hasanuzzaman M, Fahad S, Boote KJ, Hoogenboom G. 2017. Quantification the impacts of climate change and crop management on phenology of maize-based cropping system in Punjab, Pakistan. Agricultural and Forest Meteorology 247: 4255. doi: 10.1016/j.agrformet.2017.07.012

Buerki S, Davidson C, Pereira JT, Callmander MW. 2013. A new endemic species of Trigonachras (Sapindaceae) from Sabah, Malaysia (Borneo). Phytotaxa 88(2): 19-24. doi: 10.11646/phytotaxa.88.2.1

Corlett RT. 2014. The Ecology of Tropical East Asia (2nd ed.). Oxford University Press, New York. pp 24-26.

Diaz-Novellon S, Penot E, Arnaud M. 2004. Characterisation of Biodiversity in Improved Rubber Agroforests in WestKalimantan, Indonesia: Real and Potential Uses for Spontaneous Plants. In: Gerold G, Fremerey M, Guhardja E (eds.) Land Use, Nature Conservation and the Stability of Rainforest Margins in Southeast Asia. Springer, Berlin. pp 427-444. doi: 10.1007/978-3-662-08237-9_24

Dodo. 2015. Keanekaragaman dan konservasi tumbuhan langka Indonesia. Warta Kebun Raya 13(2): 37-42.

Dunham $\mathrm{AE}$, Razafindratsima $\mathrm{OH}$, Rakotonirina $\mathrm{P}$, Wright $\mathrm{PC}$. 2018. Fruiting phenology is linked to rainfall variability in a tropical rain forest. Biotropica 50(3): 396-404. doi: 10.1111/btp.12564

Dutta G, Devi A. 2015. Phenology and population structure of six tree species in tropical forest of Assam, northeast India. Tropical Ecology 56(3): 393-399. http://tropecol.com/ pdf/open/PDF_56_3/11\%20Dutta\%20\&\%20Devi.pdf

Gardiner B, Berry P, Moulia B. 2016. Review: Wind impacts on plant growth, mechanics and damage. Plant Science 245: 94-118. doi: 10.1016/j.plantsci.2016.01.006

Gardner S, Sidisunthorn P, Anusarnsunthorn V. 2000. A Field Guide to Forest Trees of Northern Thailand. Kobfai Publishing Project, Bangkok.

Gunter S, Stimm B, Cabrera M, Diaz ML, Lojan M, Ordo〜nez E, Richter M, Weber M. 2008. Tree phenology in montane forests of southern Ecuador can be explained by precipitation, radiation and photoperiodic control. Journal of Tropical Ecology 24(3): 247-258. doi: $10.1017 / \mathrm{S} 0266467408005063$

Hamann A. 2004. Flowering and fruiting phenology of a Philippine submontane rain forest: climatic factors as proximate and ultimate causes. Journal of Ecology 92(1): 24-31. https://www.jstor.org/stable/3599435

Hatta H, Mujahidin, Gumilang AR, Fijridiyanto IA, Keiko H, Darnaedi D. 2005. Phenology and growth habits of tropical trees long-term observations in the Bogor and Cibodas Botanic Gardens, Indonesia. National Science Museum Monographs 30: 1-436.
Hendrawan R, Sumiyati D, Nasrudin A, Nasution SG, Millah R. 2019. Karakteristik habitat lutung (Trachypithecus auratus É. Geoffroy, 1812) pada vegetasi hutan dataran rendah Blok Cipalawah, Cagar Alam Leuweung Sancang, Kabupaten Garut, Jawa Barat. Prosiding Seminar Nasional Masyarakat Biodiversitas Indonesia 5(2): 399405. doi: $10.13057 / \mathrm{psnmbi} / \mathrm{m} 050243$

Hong DTH. 2017. Threatened tree species across conservation zones in a nature reserve of north-western Vietnam. PhD Dissertation, Göttingen University, Göttingen.

IUCN (International Union for the Conservation of Nature). 2020. The IUCN Red List of Threatened Species. https://www.iucnredlist.org/

Jansen PCM, Jukema J, Oyen LPA, van Lingen TG. 1991. Mischocarpus pentapetalus (Roxb.) Radlk. In: Verheij EWM, Coronel RE (eds.) PROSEA: Plant Resources of South-East Asia. Vol. 2: Edible fruits and nuts. Pudoc, Wageningen. pp 347-348. https://www.proseanet.org/

Lee ATK, Carr JA, Ahmad B, Arbainsyah, Ferisa A, Handoko Y, Harsono R, Graham LLB, Kabangnga L, Kurniawan, NP, Keßler PJA, Kuncoro $P$, Prayunita $D$, Priadiati $A$, Purwanto E, Russon AE, Sheil D, Sylva N, Wahyudi A, Foden WB. 2019. Reforesting for the climate of tomorrow: Recommendations for strengthening orangutan conservation and climate change resilience in Kutai National Park, Indonesia. IUCN, Gland-Switzerland.

Luna-Nieves AL, Meave JA, Morellato LPC, Ibarra-Manríquez G. 2017. Reproductive phenology of useful seasonally dry tropical forest trees: Guiding patterns for seed collection and plant propagation in nurseries. Forest Ecology and Management 393: 52-62. doi: 10.1016/j.foreco.2017. 03.014

Makhmale S, Bhutada P, Yadav L, Yadav BK. 2016. Impact of climate change on phenology of mango-the case study. Ecology, Environment and Conservation 22 (September Suppl.): S127-S132. https://www.researchgate.net/ profile/Pritam_Bhutada/publication/309209737_Article21_Impact_of_climate_change_on_phenology_of_Mang o-

_The_case_study/links/5805ca4708aef87fbf3bc80e/Arti cle-21-Impact-of-climate-change-on-phenology-of-

Mango-The-case-study.pdf (accessed on 16 January 2020)

Manfron MP, Bajerski L, Malesuik MD, Zanetti GD. 2010. Morfoanatomia das folias de Dodonaea viscose Jacq., Sapindaceae. Revista Brasileira de Farmacognosia 20(4): 536-541. doi: 10.1590/S0102-695X2010000400012

Milow P, Malek SB, Edo J, Ong HC. 2014. Malaysian species of plants with edible fruits or seeds and their valuation. International Journal of Fruit Science 14(1): 1-27. doi: 10.1080/15538362.2013.801698

Morellato LPC, Alberton B, Alvarado ST, Borges B, Buisson E, Camargo MGG, Cancian LF, Carstensen DW, Escobar DFE, Leite PTP, Mendoza I, Rocha NMWB, Soares NC, Silva TSF, Staggemeier VG, Streher AS, Vargas BC, Peres CA. 2016. Linking plant phenology to conservation biology. 
Biological Conservation 195: 60-72. doi: 10.1016/j.biocon.2015.12.033

Mueller-Dombois D, Fosberg FR. 2013. Vegetation of the Tropical Pacific Islands. Springer Science and Business Media, New York. pp 24-30.

Nath S, Nath AJ, Das AK. 2016. Vegetative and reproductive phenology of a floodplain tree species Barringtonia acutangula from North East India. Journal of Environmental Biology 37(2): 215-220. pmid: 27097440

Normasiwi S, Surya MI. 2016. The potential fruit crop of Cibodas Botanical Garden. Biosaintifika 8(2): 206-213. doi: 10.15294/biosaintifika.v8i2.5235

Padulosi S, Heywood D, Hunter D, Jarvis A. 2011. Underutilized species and climate change: Current status and outlook. In: Yadav SS, Redden RJ, Hatfield L, Lotze-Campen $\mathrm{H}$, Hall AE (eds.) Crop Adaptation to Climate Change. John Wiley \& Sons, Inc., London. pp 507-521. doi: 10.1002/9780470960929.ch35

Pau S, Wolkovich EM, Cook BI, Davies TJ, Kraft NJB, Bolmgren K, Betancourt JL, Cleland EE. 2011. Predicting phenology by integrating ecology, evolution and climate science. Global Change Biology 17(12): 3633-3643. doi: 10.1111/j.1365-2486.2011.02515.x

Prabhakar SVRK. 2011. Climate change impacts in japan and southeast Asia: implications for crop adaptation. In: Yadav SS, Redden RJ, Hatfield L, Lotze-Campen H, Hall AE (eds.) Crop Adaptation to Climate Change. John Wiley \& Sons, Inc., London. pp 131-142. doi: 10.1002/9780470960929.ch10

Raza SA, Hussain S, Riaz H, Mahmood S. 2013. Review of beneficial and remedial aspects of Cardiospermum halicacabum L. African Journal of Pharmacy and Pharmacology 7(48): 3026-3033. doi: 10.5897/AJPP2013.3719

Registration Unit-CBG. 2018a. Annual reports of microclimates of CBG from 2012 to 2018: Form D10. Cibodas Botanic Gardens, Cianjur. [Unpublished data]

Registration Unit-CBG. 2018b. Monthly reports of plants collection richness of CBG of 2018. Cibodas Botanic Gardens, Cianjur. [Unpublished data]

Ritchie AL, Erickson TE, Merritt DJ. 2017. Monitoring of plant phenology and seed production identifies two distinct seed collection seasons in the Australian arid zone. The Rangeland Journal 39(1): 73-83. doi: 10.1071/RJ16050

Rozak AH, Astutik S, Mutaqien Z, Widyatmoko D, Sulistyawati E. 2016. Kekayaan jenis pohon di hutan Taman Nasional Gunung Gede Pangrango, Jawa Barat. Jurnal Penelitian Hutan dan Konservasi Alam 13(1): 1-14. doi: 10.20886/jphka.2016.13.1.1-14

Scheffers BR, Edwards DP, Stewart L. Macdonald SL, Senior RA, Andriamahohatra LR, Roslan N, Rogers AM, Haugaasen T, Wright P, Williams SE. 2016. Extreme thermal heterogeneity in structurally complex tropical rain forests. Biotropica 49(1): 35-44. doi: 10.1111/btp.12355

Tariq M, Ahmad S, Fahad S, Abbas G, Hussain S, Fatima Z, Nasim W, Mubeen M, ur Rehman MH, Khan MA, Adnan M, Wilkerson CJ, Hoogenboom G. 2018. The impact of climate warming and crop management on phenology of sunflower-based cropping systems in Punjab, Pakistan. Agricultural and Forest Meteorology 256-257: 270-282. doi: 10.1016/j.agrformet.2018.03.015

Underwood EC, Olson D, Hollander AD, Quinn JF. 2014. Ever-wet tropical forests as biodiversity refuges. Nature Climate Change 4: 740-741. doi: 10.1038/nclimate2351

Uji T. 2007. Review: Keanekaragaman jenis buah-buahan asli Indonesia dan potensinya. Biodiversitas 8(2): 157-167. doi: 10.13057/biodiv/d080217

Widodo A, Andawaningtyas K. 2017. Pengantar Statistika. UB Press, Malang. pp 19-20.

Williams L, Bunyavejchewin S, Baker PJ. 2008. Deciduousness in a seasonal tropical forest in western Thailand: interannual and intraspecific variation in timing, duration and environmental cues. Oecologia 155: 571582. doi: 10.1007/s00442-007-0938-1

Zeppel MJB, Wilks JV, Lewis JD. 2014. Impacts of extreme precipitation and seasonal changes in precipitation on plants. Biogeosciences 11(11): 3083-3093. doi: $10.5194 /$ bg-11-3083-2014 


\section{APPENDIX 1.}

Rank assessment of flowering and fruiting phenology of the Specimen I of M. pentapetalus from 2014 to 2018. (Rank 5, more than 80\% of flowering or fruiting (abundant); Rank 4, flowering or fruiting on 60 to $80 \%$ (moderately abundant); Rank 3, flowering or fruiting on 30 to $60 \%$ (moderate); Rank 2, flowering or fruiting less than $30 \%$ (rare), and Rank 1 without flowering or fruiting, $0 \%$ (nothing)).

\begin{tabular}{|c|c|c|c|c|c|c|c|c|c|c|c|c|c|c|c|c|}
\hline \multirow{2}{*}{$\begin{array}{l}\text { Flowering and } \\
\text { Fruiting Phase } \\
2014\end{array}$} & \multicolumn{4}{|c|}{ Jan. } & \multicolumn{4}{|c|}{ Feb. } & \multicolumn{4}{|c|}{ Mar. } & \multicolumn{4}{|c|}{ Apr. } \\
\hline & $\begin{array}{c}\text { Week } \\
1\end{array}$ & $\begin{array}{c}\text { Week } \\
2\end{array}$ & $\begin{array}{c}\text { Week } \\
3\end{array}$ & $\begin{array}{c}\text { Week } \\
4\end{array}$ & $\begin{array}{c}\text { Week } \\
1\end{array}$ & $\begin{array}{c}\text { Week } \\
2\end{array}$ & $\begin{array}{c}\text { Week } \\
3\end{array}$ & $\begin{array}{c}\text { Week } \\
4\end{array}$ & $\begin{array}{c}\text { Week } \\
1\end{array}$ & $\begin{array}{c}\text { Week } \\
2\end{array}$ & $\begin{array}{c}\text { Week } \\
3\end{array}$ & $\begin{array}{c}\text { Week } \\
4\end{array}$ & $\begin{array}{c}\text { Week } \\
1\end{array}$ & $\begin{array}{c}\text { Week } \\
2\end{array}$ & $\begin{array}{c}\text { Week } \\
3\end{array}$ & $\begin{array}{c}\text { Week } \\
4\end{array}$ \\
\hline Flower buds & 1 & 1 & 1 & 1 & 1 & 1 & 1 & 1 & 1 & 1 & 1 & 1 & 1 & 1 & 1 & 1 \\
\hline Flowering & 1 & 1 & 1 & 1 & 1 & 1 & 1 & 1 & 1 & 1 & 1 & 1 & 1 & 1 & 1 & 1 \\
\hline Young fruits & 1 & 1 & 1 & 1 & 1 & 1 & 1 & 1 & 1 & 1 & 1 & 1 & 1 & 1 & 1 & 1 \\
\hline Ripe fruits & 1 & 1 & 1 & 1 & 1 & 1 & 1 & 1 & 1 & 1 & 1 & 1 & 1 & 1 & 1 & 1 \\
\hline \multirow{2}{*}{$\begin{array}{l}\text { Flowering and } \\
\text { Fruiting Phase } \\
2014\end{array}$} & \multicolumn{4}{|c|}{ May } & \multicolumn{4}{|c|}{ Jun. } & \multicolumn{4}{|c|}{ Jul. } & \multicolumn{4}{|c|}{ Aug. } \\
\hline & $\begin{array}{c}\text { Week } \\
1\end{array}$ & $\begin{array}{c}\text { Week } \\
2\end{array}$ & $\begin{array}{c}\text { Week } \\
3\end{array}$ & $\begin{array}{c}\text { Week } \\
4\end{array}$ & $\begin{array}{c}\text { Week } \\
1\end{array}$ & $\begin{array}{c}\text { Week } \\
2\end{array}$ & $\begin{array}{c}\text { Week } \\
3\end{array}$ & $\begin{array}{c}\text { Week } \\
4\end{array}$ & $\begin{array}{c}\text { Week } \\
1\end{array}$ & $\begin{array}{c}\text { Week } \\
2\end{array}$ & $\begin{array}{c}\text { Week } \\
3\end{array}$ & $\begin{array}{c}\text { Week } \\
4\end{array}$ & $\begin{array}{c}\text { Week } \\
1\end{array}$ & $\begin{array}{c}\text { Week } \\
2\end{array}$ & $\begin{array}{c}\text { Week } \\
3\end{array}$ & $\begin{array}{c}\text { Week } \\
4\end{array}$ \\
\hline Flower buds & 1 & 1 & 1 & 1 & 1 & 1 & 1 & 1 & 1 & 1 & 1 & 1 & 1 & 1 & 1 & 1 \\
\hline Flowering & 1 & 1 & 1 & 1 & 1 & 1 & 1 & 1 & 1 & 1 & 1 & 1 & 1 & 1 & 1 & 1 \\
\hline Young fruits & 1 & 1 & 1 & 1 & 1 & 1 & 1 & 1 & 1 & 1 & 1 & 1 & 1 & 1 & 1 & 1 \\
\hline Ripe fruits & 1 & 1 & 1 & 1 & 1 & 1 & 1 & 1 & 1 & 1 & 1 & 1 & 1 & 1 & 1 & 1 \\
\hline \multirow{2}{*}{$\begin{array}{l}\text { Flowering and } \\
\text { Fruiting Phase } \\
2014\end{array}$} & \multicolumn{4}{|c|}{ Sep. } & \multicolumn{4}{|c|}{ Oct. } & \multicolumn{4}{|c|}{ Nov. } & \multicolumn{4}{|c|}{ Dec. } \\
\hline & $\begin{array}{c}\text { Week } \\
1 \\
\end{array}$ & $\begin{array}{c}\text { Week } \\
2 \\
\end{array}$ & $\begin{array}{c}\text { Week } \\
3 \\
\end{array}$ & $\begin{array}{c}\text { Week } \\
4\end{array}$ & \begin{tabular}{|c|} 
Week \\
1 \\
\end{tabular} & $\begin{array}{c}\text { Week } \\
2 \\
\end{array}$ & $\begin{array}{c}\text { Week } \\
3 \\
\end{array}$ & $\begin{array}{c}\text { Week } \\
4 \\
\end{array}$ & $\begin{array}{c}\text { Week } \\
1 \\
\end{array}$ & $\begin{array}{c}\text { Week } \\
2 \\
\end{array}$ & $\begin{array}{c}\text { Week } \\
3 \\
\end{array}$ & $\begin{array}{c}\text { Week } \\
4 \\
\end{array}$ & $\begin{array}{c}\text { Week } \\
1 \\
\end{array}$ & $\begin{array}{c}\text { Week } \\
2 \\
\end{array}$ & $\begin{array}{c}\text { Week } \\
3 \\
\end{array}$ & $\begin{array}{c}\text { Week } \\
4 \\
\end{array}$ \\
\hline Flower buds & 1 & 1 & 1 & 1 & 1 & 1 & 1 & 1 & 1 & 1 & 1 & 1 & 3 & 3 & 3 & 2 \\
\hline Flowering & 1 & 1 & 1 & 1 & 1 & 1 & 1 & 1 & 1 & 1 & 1 & 1 & 2 & 2 & 3 & 3 \\
\hline Young fruits & 1 & 1 & 1 & 1 & 1 & 1 & 1 & 1 & 1 & 1 & 1 & 1 & 1 & 1 & 1 & 1 \\
\hline Ripe fruits & 1 & 1 & 1 & 1 & 1 & 1 & 1 & 1 & 1 & 1 & 1 & 1 & 1 & 1 & 1 & 1 \\
\hline
\end{tabular}

\begin{tabular}{|c|c|c|c|c|c|c|c|c|c|c|c|c|c|c|c|c|}
\hline \multirow{2}{*}{$\begin{array}{l}\text { Flowering and } \\
\text { Fruiting Phase } \\
2015\end{array}$} & \multicolumn{4}{|c|}{ Jan. } & \multicolumn{4}{|c|}{ Feb. } & \multicolumn{4}{|c|}{ Mar. } & \multicolumn{4}{|c|}{ Apr. } \\
\hline & $\begin{array}{c}\text { Week } \\
1\end{array}$ & $\begin{array}{c}\text { Week } \\
2\end{array}$ & $\begin{array}{c}\text { Week } \\
3\end{array}$ & $\begin{array}{c}\text { Week } \\
4\end{array}$ & $\begin{array}{c}\text { Week } \\
1\end{array}$ & $\begin{array}{c}\text { Week } \\
2\end{array}$ & $\begin{array}{c}\text { Week } \\
3\end{array}$ & $\begin{array}{c}\text { Week } \\
4\end{array}$ & $\begin{array}{c}\text { Week } \\
1\end{array}$ & $\begin{array}{c}\text { Week } \\
2\end{array}$ & $\begin{array}{c}\text { Week } \\
3\end{array}$ & $\begin{array}{c}\text { Week } \\
4\end{array}$ & $\begin{array}{c}\text { Week } \\
1\end{array}$ & $\begin{array}{c}\text { Week } \\
2\end{array}$ & $\begin{array}{c}\text { Week } \\
3\end{array}$ & $\begin{array}{c}\text { Week } \\
4\end{array}$ \\
\hline Flower buds & 1 & 1 & 1 & 1 & 1 & 1 & 1 & 1 & 1 & 1 & 1 & 1 & 1 & 1 & 1 & 1 \\
\hline Flowering & 2 & 2 & 1 & 1 & 1 & 1 & 1 & 1 & 1 & 1 & 1 & 1 & 1 & 1 & 1 & 1 \\
\hline Young fruits & 2 & 4 & 3 & 3 & 3 & 3 & 3 & 3 & 3 & 2 & 3 & 2 & 1 & 2 & 1 & 2 \\
\hline Ripe fruits & 1 & 1 & 1 & 1 & 1 & 1 & 1 & 1 & 1 & 2 & 2 & 2 & 2 & 2 & 2 & 2 \\
\hline \multirow{2}{*}{$\begin{array}{l}\text { Flowering and } \\
\text { Fruiting Phase } \\
2015\end{array}$} & \multicolumn{4}{|c|}{ May } & \multicolumn{4}{|c|}{ Jun. } & \multicolumn{4}{|c|}{ Jul. } & \multicolumn{4}{|c|}{ Aug. } \\
\hline & $\begin{array}{c}\text { Week } \\
1 \\
\end{array}$ & $\begin{array}{c}\text { Week } \\
2 \\
\end{array}$ & $\begin{array}{c}\text { Week } \\
3 \\
\end{array}$ & $\begin{array}{c}\text { Week } \\
4 \\
\end{array}$ & $\begin{array}{c}\text { Week } \\
1 \\
\end{array}$ & $\begin{array}{c}\text { Week } \\
2 \\
\end{array}$ & $\begin{array}{c}\text { Week } \\
3 \\
\end{array}$ & $\begin{array}{c}\text { Week } \\
4 \\
\end{array}$ & $\begin{array}{c}\text { Week } \\
1 \\
\end{array}$ & $\begin{array}{c}\text { Week } \\
2 \\
\end{array}$ & $\begin{array}{c}\text { Week } \\
3 \\
\end{array}$ & $\begin{array}{c}\text { Week } \\
4 \\
\end{array}$ & $\begin{array}{c}\text { Week } \\
1 \\
\end{array}$ & $\begin{array}{c}\text { Week } \\
2 \\
\end{array}$ & $\begin{array}{c}\text { Week } \\
3 \\
\end{array}$ & $\begin{array}{c}\text { Week } \\
4 \\
\end{array}$ \\
\hline Flower buds & 1 & 1 & 1 & 1 & 1 & 1 & 1 & 1 & 1 & 1 & 1 & 1 & 1 & 1 & 1 & 1 \\
\hline Flowering & 1 & 1 & 1 & 1 & 1 & 1 & 1 & 1 & 1 & 1 & 1 & 1 & 1 & 1 & 1 & 1 \\
\hline Young fruits & 1 & 1 & 1 & 1 & 1 & 1 & 1 & 1 & 1 & 1 & 1 & 1 & 1 & 1 & 1 & 1 \\
\hline Ripe fruits & 1 & 1 & 1 & 1 & 1 & 1 & 1 & 1 & 1 & 1 & 1 & 1 & 1 & 1 & 1 & 1 \\
\hline \multirow{2}{*}{$\begin{array}{l}\text { Flowering and } \\
\text { Fruiting Phase } \\
2015\end{array}$} & \multicolumn{4}{|c|}{ Sep. } & \multicolumn{4}{|c|}{ Oct. } & \multicolumn{4}{|c|}{ Nov. } & \multicolumn{4}{|c|}{ Dec. } \\
\hline & $\begin{array}{c}\text { Week } \\
1\end{array}$ & $\begin{array}{c}\text { Week } \\
2\end{array}$ & $\begin{array}{c}\text { Week } \\
3\end{array}$ & $\begin{array}{c}\text { Week } \\
4\end{array}$ & $\begin{array}{c}\text { Week } \\
1\end{array}$ & $\begin{array}{c}\text { Week } \\
2\end{array}$ & $\begin{array}{c}\text { Week } \\
3\end{array}$ & $\begin{array}{c}\text { Week } \\
4\end{array}$ & $\begin{array}{c}\text { Week } \\
1\end{array}$ & $\begin{array}{c}\text { Week } \\
2\end{array}$ & $\begin{array}{c}\text { Week } \\
3 \\
\end{array}$ & $\begin{array}{c}\text { Week } \\
4\end{array}$ & $\begin{array}{c}\text { Week } \\
1\end{array}$ & $\begin{array}{c}\text { Week } \\
2\end{array}$ & $\begin{array}{c}\text { Week } \\
3\end{array}$ & $\begin{array}{c}\text { Week } \\
4\end{array}$ \\
\hline Flower buds & 1 & 1 & 1 & 1 & 1 & 1 & 3 & 1 & 2 & 3 & 3 & 3 & 3 & 2 & 2 & 2 \\
\hline Flowering & 1 & 1 & 1 & 1 & 1 & 1 & 2 & 1 & 1 & 2 & 2 & 2 & 2 & 4 & 4 & 4 \\
\hline Young fruits & 1 & 1 & 1 & 1 & 1 & 1 & 1 & 1 & 1 & 1 & 1 & 1 & 1 & 1 & 1 & 1 \\
\hline Ripe fruits & 1 & 1 & 1 & 1 & 1 & 1 & 1 & 1 & 1 & 1 & 1 & 1 & 1 & 1 & 1 & 1 \\
\hline
\end{tabular}




\begin{tabular}{|c|c|c|c|c|c|c|c|c|c|c|c|c|c|c|c|c|}
\hline \multirow{2}{*}{$\begin{array}{l}\text { Flowering and } \\
\text { Fruiting Phase } \\
2016\end{array}$} & \multicolumn{4}{|c|}{ Jan. } & \multicolumn{4}{|c|}{ Feb. } & \multicolumn{4}{|c|}{ Mar. } & \multicolumn{4}{|c|}{ Apr. } \\
\hline & $\begin{array}{c}\text { Week } \\
1 \\
\end{array}$ & $\begin{array}{c}\text { Week } \\
2 \\
\end{array}$ & $\begin{array}{c}\text { Week } \\
3 \\
\end{array}$ & $\begin{array}{c}\text { Week } \\
4 \\
\end{array}$ & $\begin{array}{c}\text { Week } \\
1 \\
\end{array}$ & $\begin{array}{c}\text { Week } \\
2 \\
\end{array}$ & $\begin{array}{c}\text { Week } \\
3 \\
\end{array}$ & $\begin{array}{c}\text { Week } \\
4 \\
\end{array}$ & $\begin{array}{c}\text { Week } \\
1 \\
\end{array}$ & $\begin{array}{c}\text { Week } \\
2 \\
\end{array}$ & $\begin{array}{c}\text { Week } \\
3 \\
\end{array}$ & $\begin{array}{c}\text { Week } \\
4 \\
\end{array}$ & $\begin{array}{c}\text { Week } \\
1 \\
\end{array}$ & $\begin{array}{c}\text { Week } \\
2 \\
\end{array}$ & $\begin{array}{c}\text { Week } \\
3 \\
\end{array}$ & $\begin{array}{c}\text { Week } \\
4 \\
\end{array}$ \\
\hline Flower buds & 1 & 1 & 1 & 1 & 1 & 1 & 1 & 1 & 1 & 1 & 1 & 1 & 1 & 1 & 1 & 1 \\
\hline Flowering & 2 & 1 & 1 & 1 & 1 & 1 & 1 & 1 & 1 & 1 & 1 & 1 & 1 & 1 & 1 & 1 \\
\hline Young fruits & 4 & 4 & 3 & 3 & 3 & 3 & 3 & 2 & 3 & 3 & 3 & 2 & 1 & 1 & 1 & 1 \\
\hline Ripe fruits & 1 & 1 & 1 & 1 & 1 & 1 & 1 & 2 & 1 & 1 & 2 & 2 & 2 & 1 & 1 & 1 \\
\hline \multirow{2}{*}{$\begin{array}{l}\text { Flowering and } \\
\text { Fruiting Phase } \\
2016\end{array}$} & \multicolumn{4}{|c|}{ May } & \multicolumn{4}{|c|}{ Jun. } & \multicolumn{4}{|c|}{ Jul. } & \multicolumn{4}{|c|}{ Aug. } \\
\hline & $\begin{array}{c}\text { Week } \\
1\end{array}$ & $\begin{array}{c}\text { Week } \\
2 \\
\end{array}$ & $\begin{array}{c}\text { Week } \\
3 \\
\end{array}$ & $\begin{array}{c}\text { Week } \\
4 \\
\end{array}$ & $\begin{array}{c}\text { Week } \\
1 \\
\end{array}$ & $\begin{array}{c}\text { Week } \\
2 \\
\end{array}$ & $\begin{array}{c}\text { Week } \\
3 \\
\end{array}$ & $\begin{array}{c}\text { Week } \\
4 \\
\end{array}$ & $\begin{array}{c}\text { Week } \\
1 \\
\end{array}$ & $\begin{array}{c}\text { Week } \\
2 \\
\end{array}$ & $\begin{array}{c}\text { Week } \\
3 \\
\end{array}$ & $\begin{array}{c}\text { Week } \\
4 \\
\end{array}$ & $\begin{array}{c}\text { Week } \\
1 \\
\end{array}$ & $\begin{array}{c}\text { Week } \\
2\end{array}$ & $\begin{array}{c}\text { Week } \\
3\end{array}$ & $\begin{array}{c}\text { Week } \\
4 \\
\end{array}$ \\
\hline Flower buds & 1 & 1 & 1 & 1 & 1 & 1 & 1 & 1 & 1 & 1 & 1 & 1 & 1 & 1 & 1 & 1 \\
\hline Flowering & 1 & 1 & 1 & 1 & 1 & 1 & 1 & 1 & 1 & 1 & 1 & 1 & 1 & 1 & 1 & 1 \\
\hline Young fruits & 1 & 1 & 1 & 1 & 1 & 1 & 1 & 1 & 1 & 1 & 1 & 1 & 1 & 1 & 1 & 1 \\
\hline Ripe fruits & 1 & 1 & 1 & 1 & 1 & 1 & 1 & 1 & 1 & 1 & 1 & 1 & 1 & 1 & 1 & 1 \\
\hline \multirow{2}{*}{$\begin{array}{l}\text { Flowering and } \\
\text { Fruiting Phase } \\
2016\end{array}$} & \multicolumn{4}{|c|}{ Sep. } & \multicolumn{4}{|c|}{ Oct. } & \multicolumn{4}{|c|}{ Nov. } & \multicolumn{4}{|c|}{ Dec. } \\
\hline & $\begin{array}{c}\text { Week } \\
1 \\
\end{array}$ & $\begin{array}{c}\text { Week } \\
2 \\
\end{array}$ & $\begin{array}{c}\text { Week } \\
3 \\
\end{array}$ & $\begin{array}{c}\text { Week } \\
4 \\
\end{array}$ & $\begin{array}{c}\text { Week } \\
1 \\
\end{array}$ & $\begin{array}{c}\text { Week } \\
2 \\
\end{array}$ & $\begin{array}{c}\text { Week } \\
3 \\
\end{array}$ & $\begin{array}{c}\text { Week } \\
4 \\
\end{array}$ & $\begin{array}{c}\text { Week } \\
1 \\
\end{array}$ & $\begin{array}{c}\text { Week } \\
2 \\
\end{array}$ & $\begin{array}{c}\text { Week } \\
3 \\
\end{array}$ & $\begin{array}{c}\text { Week } \\
4 \\
\end{array}$ & $\begin{array}{c}\text { Week } \\
1 \\
\end{array}$ & $\begin{array}{c}\text { Week } \\
2 \\
\end{array}$ & $\begin{array}{c}\text { Week } \\
3 \\
\end{array}$ & $\begin{array}{c}\text { Week } \\
4 \\
\end{array}$ \\
\hline Flower buds & 1 & 1 & 1 & 1 & 1 & 1 & 1 & 1 & 1 & 1 & 1 & 1 & 1 & 1 & 1 & 1 \\
\hline Flowering & 1 & 1 & 1 & 1 & 1 & 1 & 1 & 1 & 1 & 1 & 1 & 1 & 1 & 1 & 1 & 1 \\
\hline Young fruits & 1 & 1 & 1 & 1 & 1 & 1 & 1 & 1 & 1 & 1 & 1 & 1 & 1 & 1 & 1 & 1 \\
\hline Ripe fruits & 1 & 1 & 1 & 1 & 1 & 1 & 1 & 1 & 1 & 1 & 1 & 1 & 1 & 1 & 1 & 1 \\
\hline
\end{tabular}

\begin{tabular}{|c|c|c|c|c|c|c|c|c|c|c|c|c|c|c|c|c|}
\hline \multirow{2}{*}{$\begin{array}{l}\text { Flowering and } \\
\text { Fruiting Phase } \\
2017\end{array}$} & \multicolumn{4}{|c|}{ Jan. } & \multicolumn{4}{|c|}{ Feb. } & \multicolumn{4}{|c|}{ Mar. } & \multicolumn{4}{|c|}{ Apr. } \\
\hline & $\begin{array}{c}\text { Week } \\
1\end{array}$ & $\begin{array}{c}\text { Week } \\
2 \\
\end{array}$ & $\begin{array}{c}\text { Week } \\
3 \\
\end{array}$ & $\begin{array}{c}\text { Week } \\
4 \\
\end{array}$ & $\begin{array}{c}\text { Week } \\
1\end{array}$ & $\begin{array}{c}\text { Week } \\
2 \\
\end{array}$ & $\begin{array}{c}\text { Week } \\
3 \\
\end{array}$ & $\begin{array}{c}\text { Week } \\
4\end{array}$ & $\begin{array}{c}\text { Week } \\
1 \\
\end{array}$ & $\begin{array}{c}\text { Week } \\
2 \\
\end{array}$ & $\begin{array}{c}\text { Week } \\
3 \\
\end{array}$ & $\begin{array}{c}\text { Week } \\
4 \\
\end{array}$ & $\begin{array}{c}\text { Week } \\
1\end{array}$ & $\begin{array}{c}\text { Week } \\
2 \\
\end{array}$ & $\begin{array}{c}\text { Week } \\
3 \\
\end{array}$ & $\begin{array}{c}\text { Week } \\
4 \\
\end{array}$ \\
\hline Flower buds & 1 & 1 & 1 & 1 & 1 & 1 & 1 & 1 & 1 & 1 & 1 & 1 & 1 & 1 & 1 & 1 \\
\hline Flowering & 1 & 1 & 1 & 1 & 1 & 1 & 1 & 1 & 1 & 1 & 1 & 1 & 1 & 1 & 1 & 1 \\
\hline Young fruits & 1 & 1 & 1 & 1 & 1 & 1 & 1 & 1 & 1 & 1 & 1 & 1 & 1 & 1 & 1 & 1 \\
\hline Ripe fruits & 1 & 1 & 1 & 1 & 1 & 1 & 1 & 1 & 1 & 1 & 1 & 1 & 1 & 1 & 1 & 1 \\
\hline \multirow{2}{*}{$\begin{array}{l}\text { Flowering and } \\
\text { Fruiting Phase } \\
2017\end{array}$} & \multicolumn{4}{|c|}{ May } & \multicolumn{4}{|c|}{ Jun. } & \multicolumn{4}{|c|}{ Jul. } & \multicolumn{4}{|c|}{ Aug. } \\
\hline & $\begin{array}{c}\text { Week } \\
1 \\
\end{array}$ & $\begin{array}{c}\text { Week } \\
2\end{array}$ & $\begin{array}{c}\text { Week } \\
3 \\
\end{array}$ & $\begin{array}{c}\text { Week } \\
4 \\
\end{array}$ & $\begin{array}{c}\text { Week } \\
1 \\
\end{array}$ & \begin{tabular}{|c|} 
Week \\
2 \\
\end{tabular} & $\begin{array}{c}\text { Week } \\
3 \\
\end{array}$ & $\begin{array}{c}\text { Week } \\
4 \\
\end{array}$ & $\begin{array}{c}\text { Week } \\
1 \\
\end{array}$ & $\begin{array}{c}\text { Week } \\
2 \\
\end{array}$ & $\begin{array}{c}\text { Week } \\
3 \\
\end{array}$ & $\begin{array}{c}\text { Week } \\
4 \\
\end{array}$ & \begin{tabular}{c|} 
Week \\
1 \\
\end{tabular} & $\begin{array}{c}\text { Week } \\
2 \\
\end{array}$ & $\begin{array}{c}\text { Week } \\
3 \\
\end{array}$ & $\begin{array}{c}\text { Week } \\
4\end{array}$ \\
\hline Flower buds & 1 & 1 & 1 & 1 & 1 & 1 & 1 & 1 & 1 & 1 & 1 & 1 & 1 & 1 & 1 & 1 \\
\hline Flowering & 1 & 1 & 1 & 1 & 1 & 1 & 1 & 1 & 1 & 1 & 1 & 1 & 1 & 1 & 1 & 1 \\
\hline Young fruits & 1 & 1 & 1 & 1 & 1 & 1 & 1 & 1 & 1 & 1 & 1 & 1 & 1 & 1 & 1 & 1 \\
\hline Ripe fruits & 1 & 1 & 1 & 1 & 1 & 1 & 1 & 1 & 1 & 1 & 1 & 1 & 1 & 1 & 1 & 1 \\
\hline \multirow{2}{*}{$\begin{array}{l}\text { Flowering and } \\
\text { Fruiting Phase } \\
2017\end{array}$} & \multicolumn{4}{|c|}{ Sep. } & \multicolumn{4}{|c|}{ Oct. } & \multicolumn{4}{|c|}{ Nov. } & \multicolumn{4}{|c|}{ Dec. } \\
\hline & $\begin{array}{c}\text { Week } \\
1 \\
\end{array}$ & $\begin{array}{c}\text { Week } \\
2 \\
\end{array}$ & $\begin{array}{c}\text { Week } \\
3 \\
\end{array}$ & $\begin{array}{c}\text { Week } \\
4 \\
\end{array}$ & $\begin{array}{c}\text { Week } \\
1 \\
\end{array}$ & $\begin{array}{c}\text { Week } \\
2 \\
\end{array}$ & $\begin{array}{c}\text { Week } \\
3 \\
\end{array}$ & $\begin{array}{c}\text { Week } \\
4 \\
\end{array}$ & $\begin{array}{c}\text { Week } \\
1 \\
\end{array}$ & $\begin{array}{c}\text { Week } \\
2 \\
\end{array}$ & $\begin{array}{c}\text { Week } \\
3 \\
\end{array}$ & $\begin{array}{c}\text { Week } \\
4 \\
\end{array}$ & $\begin{array}{c}\text { Week } \\
1 \\
\end{array}$ & $\begin{array}{c}\text { Week } \\
2 \\
\end{array}$ & $\begin{array}{c}\text { Week } \\
3 \\
\end{array}$ & $\begin{array}{c}\text { Week } \\
4 \\
\end{array}$ \\
\hline Flower buds & 1 & 1 & 1 & 1 & 1 & 1 & 1 & 1 & 1 & 1 & 1 & 1 & 1 & 1 & 1 & 1 \\
\hline Flowering & 1 & 1 & 1 & 1 & 1 & 1 & 1 & 1 & 1 & 1 & 1 & 1 & 1 & 1 & 1 & 1 \\
\hline Young fruits & 1 & 1 & 1 & 1 & 1 & 1 & 1 & 1 & 1 & 1 & 1 & 1 & 1 & 1 & 1 & 1 \\
\hline Ripe fruits & 1 & 1 & 1 & 1 & 1 & 1 & 1 & 1 & 1 & 1 & 1 & 1 & 1 & 1 & 1 & 1 \\
\hline
\end{tabular}




\begin{tabular}{|c|c|c|c|c|c|c|c|c|c|c|c|c|c|c|c|c|}
\hline \multirow{2}{*}{$\begin{array}{l}\text { Flowering and } \\
\text { Fruiting Phase } \\
2018\end{array}$} & \multicolumn{4}{|c|}{ Jan. } & \multicolumn{4}{|c|}{ Feb. } & \multicolumn{4}{|c|}{ Mar. } & \multicolumn{4}{|c|}{ Apr. } \\
\hline & $\begin{array}{c}\text { Week } \\
1 \\
\end{array}$ & $\begin{array}{c}\text { Week } \\
2 \\
\end{array}$ & $\begin{array}{c}\text { Week } \\
3 \\
\end{array}$ & $\begin{array}{c}\text { Week } \\
4 \\
\end{array}$ & $\begin{array}{c}\text { Week } \\
1 \\
\end{array}$ & $\begin{array}{c}\text { Week } \\
2 \\
\end{array}$ & $\begin{array}{c}\text { Week } \\
3 \\
\end{array}$ & $\begin{array}{c}\text { Week } \\
4 \\
\end{array}$ & $\begin{array}{c}\text { Week } \\
1 \\
\end{array}$ & $\begin{array}{c}\text { Week } \\
2 \\
\end{array}$ & $\begin{array}{c}\text { Week } \\
3 \\
\end{array}$ & $\begin{array}{c}\text { Week } \\
4 \\
\end{array}$ & $\begin{array}{c}\text { Week } \\
1 \\
\end{array}$ & $\begin{array}{c}\text { Week } \\
2 \\
\end{array}$ & $\begin{array}{c}\text { Week } \\
3 \\
\end{array}$ & $\begin{array}{c}\text { Week } \\
4 \\
\end{array}$ \\
\hline Flower buds & 1 & 1 & 1 & 1 & 1 & 1 & 1 & 1 & 1 & 1 & 1 & 1 & 1 & 1 & 1 & 1 \\
\hline Flowering & 1 & 1 & 1 & 1 & 1 & 1 & 1 & 1 & 1 & 1 & 1 & 1 & 1 & 1 & 1 & 1 \\
\hline Young fruits & 1 & 1 & 3 & 1 & 1 & 1 & 1 & 1 & 1 & 1 & 1 & 1 & 1 & 1 & 1 & 1 \\
\hline Ripe fruits & 1 & 1 & 2 & 1 & 1 & 1 & 1 & 1 & 1 & 1 & 1 & 1 & 1 & 1 & 1 & 1 \\
\hline \multirow{2}{*}{$\begin{array}{l}\text { Flowering and } \\
\text { Fruiting Phase } \\
2018\end{array}$} & \multicolumn{4}{|c|}{ May } & \multicolumn{4}{|c|}{ Jun. } & \multicolumn{4}{|c|}{ Jul. } & \multicolumn{4}{|c|}{ Aug. } \\
\hline & $\begin{array}{c}\text { Week } \\
1 \\
\end{array}$ & $\begin{array}{c}\text { Week } \\
2 \\
\end{array}$ & $\begin{array}{c}\text { Week } \\
3 \\
\end{array}$ & \begin{tabular}{|c|} 
Week \\
4 \\
\end{tabular} & $\begin{array}{c}\text { Week } \\
1 \\
\end{array}$ & $\begin{array}{c}\text { Week } \\
2\end{array}$ & $\begin{array}{c}\text { Week } \\
3 \\
\end{array}$ & $\begin{array}{c}\text { Week } \\
4 \\
\end{array}$ & $\begin{array}{c}\text { Week } \\
1 \\
\end{array}$ & \begin{tabular}{c|} 
Week \\
2 \\
\end{tabular} & $\begin{array}{c}\text { Week } \\
3 \\
\end{array}$ & $\begin{array}{c}\text { Week } \\
4 \\
\end{array}$ & $\begin{array}{c}\text { Week } \\
1 \\
\end{array}$ & $\begin{array}{c}\text { Week } \\
2 \\
\end{array}$ & $\begin{array}{c}\text { Week } \\
3 \\
\end{array}$ & $\begin{array}{c}\text { Week } \\
4 \\
\end{array}$ \\
\hline Flower buds & 1 & 1 & 1 & 1 & 1 & 1 & 1 & 1 & 1 & 1 & 1 & 1 & 1 & 1 & 1 & 1 \\
\hline Flowering & 1 & 1 & 1 & 1 & 1 & 1 & 1 & 1 & 1 & 1 & 1 & 1 & 1 & 1 & 1 & 1 \\
\hline Young fruits & 1 & 1 & 1 & 1 & 1 & 1 & 1 & 1 & 1 & 1 & 1 & 1 & 1 & 1 & 1 & 1 \\
\hline Ripe fruits & 1 & 1 & 1 & 1 & 1 & 1 & 1 & 1 & 1 & 1 & 1 & 1 & 1 & 1 & 1 & 1 \\
\hline \multirow{2}{*}{$\begin{array}{l}\text { Flowering and } \\
\text { Fruiting Phase } \\
2018\end{array}$} & \multicolumn{4}{|c|}{ Sep. } & \multicolumn{4}{|c|}{ Oct. } & \multicolumn{4}{|c|}{ Nov. } & \multicolumn{4}{|c|}{ Dec. } \\
\hline & $\begin{array}{c}\text { Week } \\
1\end{array}$ & $\begin{array}{c}\text { Week } \\
2\end{array}$ & $\begin{array}{c}\text { Week } \\
3\end{array}$ & $\begin{array}{c}\text { Week } \\
4\end{array}$ & $\begin{array}{c}\text { Week } \\
1\end{array}$ & $\begin{array}{c}\text { Week } \\
2\end{array}$ & $\begin{array}{c}\text { Week } \\
3\end{array}$ & $\begin{array}{c}\text { Week } \\
4\end{array}$ & $\begin{array}{c}\text { Week } \\
1\end{array}$ & $\begin{array}{c}\text { Week } \\
2\end{array}$ & $\begin{array}{c}\text { Week } \\
3\end{array}$ & $\begin{array}{c}\text { Week } \\
4\end{array}$ & $\begin{array}{c}\text { Week } \\
1\end{array}$ & $\begin{array}{c}\text { Week } \\
2\end{array}$ & $\begin{array}{c}\text { Week } \\
3\end{array}$ & $\begin{array}{c}\text { Week } \\
4\end{array}$ \\
\hline Flower buds & 1 & 1 & 1 & 1 & 1 & 1 & 1 & 3 & 3 & 2 & 3 & 3 & 3 & 3 & 2 & 2 \\
\hline Flowering & 1 & 1 & 1 & 1 & 1 & 1 & 1 & 2 & 3 & 1 & 2 & 2 & 2 & 2 & 2 & 2 \\
\hline Young fruits & 1 & 1 & 1 & 1 & 1 & 1 & 1 & 1 & 1 & 1 & 1 & 1 & 1 & 1 & 1 & 1 \\
\hline Ripe fruits & 1 & 1 & 1 & 1 & 1 & 1 & 1 & 1 & 1 & 1 & 1 & 1 & 1 & 1 & 1 & 1 \\
\hline
\end{tabular}




\section{APPENDIX 2.}

Rank assessment of flowering and fruiting phenology of the Specimen II of M. pentapetalus in 2019. (Rank 5, more than 80\% of flowering or fruiting (abundant); Rank 4, flowering or fruiting on 60 to 80\% (moderately abundant); Rank 3, flowering or fruiting on 30 to $60 \%$ (moderate); Rank 2, flowering or fruiting less than $30 \%$ (rare), and Rank 1 without flowering or fruiting, $0 \%$ (nothing)).

\begin{tabular}{|c|c|c|c|c|c|c|c|c|c|c|c|c|c|c|c|c|}
\hline \multirow{2}{*}{$\begin{array}{l}\text { Flowering and } \\
\text { Fruiting Phase }\end{array}$} & \multicolumn{4}{|c|}{ Jan. } & \multicolumn{4}{|c|}{ Feb. } & \multicolumn{4}{|c|}{ Mar. } & \multicolumn{4}{|c|}{ Apr. } \\
\hline & $\begin{array}{c}\text { Week } \\
1 \\
\end{array}$ & $\begin{array}{c}\text { Week } \\
2 \\
\end{array}$ & $\begin{array}{c}\text { Week } \\
3 \\
\end{array}$ & $\begin{array}{c}\text { Week } \\
4 \\
\end{array}$ & $\begin{array}{c}\text { Week } \\
1 \\
\end{array}$ & $\begin{array}{c}\text { Week } \\
2 \\
\end{array}$ & $\begin{array}{c}\text { Week } \\
3 \\
\end{array}$ & $\begin{array}{c}\text { Week } \\
4 \\
\end{array}$ & $\begin{array}{c}\text { Week } \\
1 \\
\end{array}$ & $\begin{array}{c}\text { Week } \\
2 \\
\end{array}$ & $\begin{array}{c}\text { Week } \\
3 \\
\end{array}$ & $\begin{array}{c}\text { Week } \\
4 \\
\end{array}$ & $\begin{array}{c}\text { Week } \\
1 \\
\end{array}$ & $\begin{array}{c}\text { Week } \\
2 \\
\end{array}$ & $\begin{array}{c}\text { Week } \\
3 \\
\end{array}$ & $\begin{array}{c}\text { Week } \\
4 \\
\end{array}$ \\
\hline Flower buds & 1 & 1 & 1 & 1 & 1 & 1 & 1 & 1 & 1 & 1 & 1 & 1 & 1 & 1 & 1 & 1 \\
\hline Flowering & 1 & 1 & 1 & 1 & 1 & 1 & 1 & 1 & 1 & 1 & 1 & 1 & 1 & 1 & 1 & 1 \\
\hline Young fruits & 4 & 4 & 4 & 4 & 3 & 4 & 4 & 4 & 3 & 3 & 2 & 2 & 1 & 1 & 1 & 1 \\
\hline Ripe fruits & 2 & 1 & 2 & 1 & 2 & 2 & 2 & 2 & 2 & 2 & 3 & 3 & 2 & 2 & 1 & 1 \\
\hline \multirow{2}{*}{$\begin{array}{l}\text { Flowering and } \\
\text { Fruiting Phase }\end{array}$} & \multicolumn{4}{|c|}{ May } & \multicolumn{4}{|c|}{ Jun. } & \multicolumn{4}{|c|}{ Jul. } & \multicolumn{4}{|c|}{ Aug. } \\
\hline & $\begin{array}{c}\text { Week } \\
1 \\
\end{array}$ & $\begin{array}{c}\text { Week } \\
2 \\
\end{array}$ & $\begin{array}{c}\text { Week } \\
3 \\
\end{array}$ & $\begin{array}{c}\text { Week } \\
4 \\
\end{array}$ & $\begin{array}{c}\text { Week } \\
1 \\
\end{array}$ & $\begin{array}{c}\text { Week } \\
2 \\
\end{array}$ & $\begin{array}{c}\text { Week } \\
3 \\
\end{array}$ & $\begin{array}{c}\text { Week } \\
4 \\
\end{array}$ & $\begin{array}{c}\text { Week } \\
1 \\
\end{array}$ & $\begin{array}{c}\text { Week } \\
2 \\
\end{array}$ & $\begin{array}{c}\text { Week } \\
3 \\
\end{array}$ & $\begin{array}{c}\text { Week } \\
4 \\
\end{array}$ & $\begin{array}{c}\text { Week } \\
1\end{array}$ & \begin{tabular}{|c|} 
Week \\
2 \\
\end{tabular} & $\begin{array}{c}\text { Week } \\
3 \\
\end{array}$ & $\begin{array}{c}\text { Week } \\
4\end{array}$ \\
\hline Flower buds & 1 & 1 & 1 & 1 & 1 & 1 & 1 & 1 & 1 & 1 & 1 & 1 & 1 & 1 & 1 & 1 \\
\hline Flowering & 1 & 1 & 1 & 1 & 1 & 1 & 1 & 1 & 1 & 1 & 1 & 1 & 1 & 1 & 1 & 1 \\
\hline Young fruits & 1 & 1 & 1 & 1 & 1 & 1 & 1 & 1 & 1 & 1 & 1 & 1 & 1 & 1 & 1 & 1 \\
\hline Ripe fruits & 1 & 1 & 1 & 1 & 1 & 1 & 1 & 1 & 1 & 1 & 1 & 1 & 1 & 1 & 1 & 1 \\
\hline $\begin{array}{l}\text { Flowering and } \\
\text { Fruiting Phase }\end{array}$ & $\begin{array}{c}\text { Week } \\
1 \\
\end{array}$ & $\begin{array}{c}\text { Week } \\
2 \\
\end{array}$ & $\begin{array}{c}\text { Week } \\
3 \\
\end{array}$ & $\begin{array}{c}\text { Week } \\
4 \\
\end{array}$ & $\begin{array}{c}\text { Week } \\
1 \\
\end{array}$ & $\begin{array}{c}\text { Week } \\
2 \\
\end{array}$ & $\begin{array}{c}\text { Week } \\
3 \\
\end{array}$ & $\begin{array}{c}\text { Week } \\
4 \\
\end{array}$ & $\begin{array}{c}\text { Week } \\
1 \\
\end{array}$ & $\begin{array}{c}\text { Week } \\
2 \\
\end{array}$ & $\begin{array}{c}\text { Week } \\
3 \\
\end{array}$ & $\begin{array}{c}\text { Week } \\
4 \\
\end{array}$ & $\begin{array}{c}\text { Week } \\
1 \\
\end{array}$ & \begin{tabular}{|c|} 
Week \\
2 \\
\end{tabular} & $\begin{array}{c}\text { Week } \\
3 \\
\end{array}$ & $\begin{array}{c}\text { Week } \\
4 \\
\end{array}$ \\
\hline Flower buds & 1 & 1 & 1 & 1 & 1 & 1 & 1 & 1 & 1 & 1 & 3 & 3 & 4 & 3 & 1 & 1 \\
\hline Flowering & 1 & 1 & 1 & 1 & 1 & 1 & 1 & 1 & 1 & 1 & 1 & 2 & 3 & 3 & 3 & 1 \\
\hline Young fruits & 1 & 1 & 1 & 1 & 1 & 1 & 1 & 1 & 1 & 1 & 1 & 1 & 2 & 2 & 2 & 3 \\
\hline Ripe fruits & 1 & 1 & 1 & 1 & 1 & 1 & 1 & 1 & 1 & 1 & 1 & 1 & 1 & 1 & 1 & 1 \\
\hline
\end{tabular}

\section{APPENDIX 3.}

Rank assessment of flowering and fruiting phenology of the Specimen III of M. pentapetalus in 2019. (Rank 5, more than $80 \%$ of flowering or fruiting (abundant); Rank 4, flowering or fruiting on 60 to $80 \%$ (moderately abundant); Rank 3, flowering or fruiting on 30 to $60 \%$ (moderate); Rank 2, flowering or fruiting less than $30 \%$ (rare), and Rank 1 without flowering or fruiting, $0 \%$ (nothing)).

\begin{tabular}{|c|c|c|c|c|c|c|c|c|c|c|c|c|c|c|c|c|}
\hline \multirow{2}{*}{$\begin{array}{l}\text { Flowering and } \\
\text { Fruiting Phase }\end{array}$} & \multicolumn{4}{|c|}{ Jan. } & \multicolumn{4}{|c|}{ Feb. } & \multicolumn{4}{|c|}{ Mar. } & \multicolumn{4}{|c|}{ Apr. } \\
\hline & $\begin{array}{c}\text { Week } \\
1\end{array}$ & $\begin{array}{c}\text { Week } \\
2\end{array}$ & $\begin{array}{c}\text { Week } \\
3\end{array}$ & $\begin{array}{c}\text { Week } \\
4\end{array}$ & $\begin{array}{c}\text { Week } \\
1\end{array}$ & $\begin{array}{c}\text { Week } \\
2\end{array}$ & $\begin{array}{c}\text { Week } \\
3\end{array}$ & $\begin{array}{c}\text { Week } \\
4\end{array}$ & $\begin{array}{c}\text { Week } \\
1\end{array}$ & $\begin{array}{c}\text { Week } \\
2\end{array}$ & $\begin{array}{c}\text { Week } \\
3\end{array}$ & $\begin{array}{c}\text { Week } \\
4\end{array}$ & $\begin{array}{c}\text { Week } \\
1\end{array}$ & $\begin{array}{c}\text { Week } \\
2\end{array}$ & $\begin{array}{c}\text { Week } \\
3\end{array}$ & $\begin{array}{c}\text { Week } \\
4\end{array}$ \\
\hline Flower buds & 4 & 1 & 1 & 1 & 1 & 1 & 1 & 1 & 1 & 1 & 1 & 1 & 1 & 1 & 1 & 1 \\
\hline Flowering & 2 & 4 & 1 & 1 & 1 & 1 & 1 & 1 & 1 & 1 & 1 & 1 & 1 & 1 & 1 & 1 \\
\hline Young fruits & 2 & 2 & 4 & 3 & 2 & 2 & 2 & 2 & 2 & 1 & 1 & 1 & 1 & 1 & 1 & 1 \\
\hline Ripe fruits & 1 & 1 & 1 & 2 & 2 & 2 & 2 & 2 & 2 & 2 & 2 & 1 & 1 & 1 & 1 & 1 \\
\hline \multirow{2}{*}{$\begin{array}{l}\text { Flowering and } \\
\text { Fruiting Phase }\end{array}$} & \multicolumn{4}{|c|}{ May } & \multicolumn{4}{|c|}{ Jun. } & \multicolumn{4}{|c|}{ Jul. } & \multicolumn{4}{|c|}{ Aug. } \\
\hline & $\begin{array}{c}\text { Week } \\
1 \\
\end{array}$ & $\begin{array}{c}\text { Week } \\
2 \\
\end{array}$ & $\begin{array}{c}\text { Week } \\
3 \\
\end{array}$ & $\begin{array}{c}\text { Week } \\
4 \\
\end{array}$ & $\begin{array}{c}\text { Week } \\
1 \\
\end{array}$ & $\begin{array}{c}\text { Week } \\
2 \\
\end{array}$ & $\begin{array}{c}\text { Week } \\
3 \\
\end{array}$ & $\begin{array}{c}\text { Week } \\
4 \\
\end{array}$ & $\begin{array}{c}\text { Week } \\
1 \\
\end{array}$ & $\begin{array}{c}\text { Week } \\
2 \\
\end{array}$ & $\begin{array}{c}\text { Week } \\
3 \\
\end{array}$ & $\begin{array}{c}\text { Week } \\
4 \\
\end{array}$ & $\begin{array}{c}\text { Week } \\
1 \\
\end{array}$ & $\begin{array}{c}\text { Week } \\
2 \\
\end{array}$ & $\begin{array}{c}\text { Week } \\
3 \\
\end{array}$ & $\begin{array}{c}\text { Week } \\
4\end{array}$ \\
\hline Flower buds & 1 & 1 & 1 & 1 & 1 & 1 & 1 & 1 & 1 & 1 & 1 & 1 & 1 & 1 & 1 & 1 \\
\hline Flowering & 1 & 1 & 1 & 1 & 1 & 1 & 1 & 1 & 1 & 1 & 1 & 1 & 1 & 1 & 1 & 1 \\
\hline Young fruits & 1 & 1 & 1 & 1 & 1 & 1 & 1 & 1 & 1 & 1 & 1 & 1 & 1 & 1 & 1 & 1 \\
\hline Ripe fruits & 1 & 1 & 1 & 1 & 1 & 1 & 1 & 1 & 1 & 1 & 1 & 1 & 1 & 1 & 1 & 1 \\
\hline \multirow{2}{*}{$\begin{array}{l}\text { Flowering and } \\
\text { Fruiting Phase }\end{array}$} & \multicolumn{4}{|c|}{ Sep. } & \multicolumn{4}{|c|}{ Oct. } & \multicolumn{4}{|c|}{ Nov. } & \multicolumn{4}{|c|}{ Dec. } \\
\hline & $\begin{array}{c}\text { Week } \\
1 \\
\end{array}$ & $\begin{array}{c}\text { Week } \\
2 \\
\end{array}$ & $\begin{array}{c}\text { Week } \\
3 \\
\end{array}$ & $\begin{array}{c}\text { Week } \\
4 \\
\end{array}$ & $\begin{array}{c}\text { Week } \\
1 \\
\end{array}$ & $\begin{array}{c}\text { Week } \\
2 \\
\end{array}$ & $\begin{array}{c}\text { Week } \\
3 \\
\end{array}$ & $\begin{array}{c}\text { Week } \\
4 \\
\end{array}$ & $\begin{array}{c}\text { Week } \\
1 \\
\end{array}$ & $\begin{array}{c}\text { Week } \\
2 \\
\end{array}$ & $\begin{array}{c}\text { Week } \\
3 \\
\end{array}$ & $\begin{array}{c}\text { Week } \\
4 \\
\end{array}$ & $\begin{array}{c}\text { Week } \\
1 \\
\end{array}$ & $\begin{array}{c}\text { Week } \\
2 \\
\end{array}$ & $\begin{array}{c}\text { Week } \\
3 \\
\end{array}$ & $\begin{array}{c}\text { Week } \\
4 \\
\end{array}$ \\
\hline Flower buds & 1 & 1 & 1 & 1 & 1 & 1 & 2 & 2 & 2 & 2 & 2 & 2 & 3 & 2 & 2 & 2 \\
\hline Flowering & 1 & 1 & 1 & 1 & 1 & 1 & 2 & 1 & 1 & 2 & 2 & 2 & 3 & 4 & 4 & 4 \\
\hline Young fruits & 1 & 1 & 1 & 1 & 1 & 1 & 1 & 1 & 1 & 1 & 1 & 1 & 1 & 1 & 1 & 1 \\
\hline Ripe fruits & 1 & 1 & 1 & 1 & 1 & 1 & 1 & 1 & 1 & 1 & 1 & 1 & 1 & 1 & 1 & 1 \\
\hline
\end{tabular}

